\title{
Chronic Hepatitis C Treatment with New Antiviral Agents
}

\author{
Yeni Antiviraller Eşliğinde Kronik Hepatit C Tedavisi
}

\section{(1) Özlem KANDEMIR}

Mersin University Faculty of Medicine, Department of Infectious Diseases and Clinical Microbiology, Mersin, Turkey

\section{Abstract}

Recent advances in our knowledge of hepatitis $\mathrm{C}$ virus (HCV) molecular biology have enabled improvements in the efficacy and tolerability of HCV treatment, and in this regard many direct-acting antiviral (DAA) agents have been developed. These drugs target specific stages in the HCV life cycle. Phase 3 clinical trials have demonstrated treatment success rates of 90\% with these drugs and their combinations, while real world data indicate a rate of 80-90\%. In this review, the use of DAA drugs in the treatment of chronic HCV infection is reviewed in detail.

Keywords: Telaprevir, boceprevir, grazoprevir, paritaprevir, simeprevir, asunaprevir, sofosbuvir

\section{Öz}

Günümüzde hepatit C virüsü (HCV) moleküler biyolojisinde artan bilgiler, HCV tedavisinin etkinliği ve tolerabilitesini iyileștirme çabalarına olanak sağlamış ve bu doğrultuda birçok direkt etkili antiviral (DEA) ajan geliştirilmiştir. Bunlar HCV yaşam siklusu içinde spesifik aşamaları hedefleyen ilaçlardır. Faz 3 çalışmalarında bu ilaçlar ve kombinasyonları ile tedavi başarısı >\%90 bulunurken, gerçek yaşam verilerinde bu oran $\% 80-90$ arasında değişmektedir. Bu derlemede kronik HCV enfeksiyonu tedavisinde DEA ilaçların kullanımı detaylı olarak gözden geçirilecektir.

Anahtar Kelimeler: Telaprevir, boceprevir, grazoprevir, paritaprevir, simeprevir, asunaprevir, sofosbuvir

\section{Introduction}

There are currently about 170 million people with chronic hepatitis $\mathrm{C}$ virus (HCV) infections worldwide, and 3-4 million new infections are reported each year. In addition, almost 350 thousand lives are lost every year due to HCV-related complications $^{[1,2]}$.

The goal of treatment for chronic HCV infections is eradication of the virus (defined as HCV RNA negativity), which is referred to as achieving sustained virologic response (SVR). Sustained virologic response is associated with long-term absence of HCV RNA in 97-100\% of cases, and is thus considered a cure for HCV infection ${ }^{[3]}$. Sustained virologic response is associated with reductions in hepatic complications, liver transplant rates, hepatocellular cancer rates, and liver-related mortality ${ }^{[3]}$.
Viral genotype is one of the most important factors determining the choice of treatment in chronic HCV. The global prevalence of anti-HCV positivity is $1.6 \%$, and the most common HCV genotype is genotype 1 (46\%), followed by genotype 3 (30\%). Genotypes 2, 4, and 6 account for $23 \%$ of all cases, while genotype 5 causes the remaining 1\%[4]. Community-based studies conducted in Turkey have reported anti-HCV positivity rates of $0.4-2.1 \%$, with genotype 1 being the most common (91.8-93.3\%), followed by genotypes 3 (3.7-4.9\%), 2 (1.5-2.2\%), and $4(1.1-2.5 \%)$. Genotype $1 \mathrm{~b}$ accounts for approximately $80 \%$ of HCV genotype 1 cases $^{[5-7]}$.

For many years, treatment of HCV infection was based solely on the combination of pegylated interferon (peg-IFN) and ribavirin (R). These drugs influence host immune factors to inhibit viral replication and also have a slight direct antiviral

Cite this article as: Kandemir Ö. Chronic Hepatitis C Treatment with New Antiviral Agents. Mediterr J Infect Microb Antimicrob. 2018;7:9. 
effect. They both have indirect antiviral effects, since neither targets specific HCV proteins or nucleic acids. More importantly, the major disadvantages of this dual therapy are its limited effectiveness (especially for genotype $1 \mathrm{HCV}$ infections, in which viral eradication is achieved in only $50 \%$ of patients) and low treatment adherence due to side effects ${ }^{[8]}$.

In recent years, our better understanding of HCV molecular biology has enabled improvements in the efficacy and tolerability of HCV treatment, leading to the development of numerous direct-acting antiviral agents (DAAs). Desirable features of DAAs include high efficacy, minimum adverse effects and interactions with other drugs, good tolerability, high genetic barrier to resistance, and low cost ${ }^{[9]}$.

These agents are targeted at specific stages of the HCV life cycle. Direct-acting antiviral agents exert their effect on the various nonstructural (NS) viral proteins (NS3-4A protease, NS5B polymerase, and NS5A protein), thus inhibiting viral replication and infection. Based on their mechanisms of action and therapeutic targets, there are currently four classes of DAA which target these three HCV proteins ${ }^{[10]}$. Phase 2 and 3 trials demonstrated over 90\% treatment success with these DAAs and their combinations. Success rates of $80-90 \%$ with DAA treatment were also reported in real world data ${ }^{[11]}$. In this article, the use of DAA agents in the treatment of chronic HCV infection is reviewed.

\section{HCV Life Cycle and Therapeutic Targets}

Infectious viral structures consist of the viral core protein and RNA enclosed within an envelope composed of glycoproteins and a lipid bilayer. Infection begins when HCV adsorbs to and penetrates the target cell (Figure 1$)^{[12]}$. This phase involves a complex interaction between envelope proteins E1/E2 and cellular receptors ${ }^{[13,14]}$.

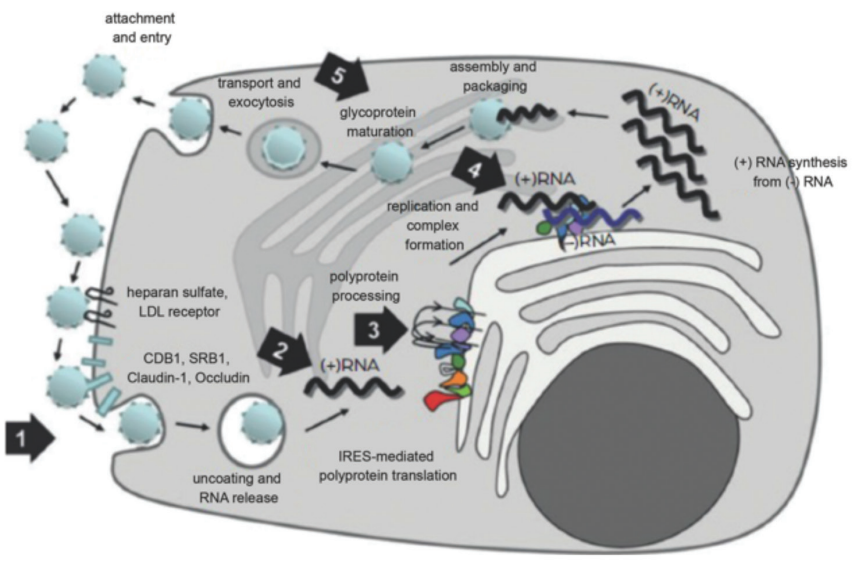

Figure 1. Life cycle of HCV. (1) Entry inhibitors, (2) Translation inhibitors, (3) Posttranslation inhibitors, (4) Replication inhibitors, (5) Assembly and packaging inhibitors ${ }^{[12]}$
Following entry into the cell, HCV RNA is released into the cytoplasm. The HCV genome synthesizes a large polyprotein of 3100 amino acids. After translation, this polyprotein is processed by host and viral proteases to yield 10 mature proteins. Some of these are structural and others are NS proteins. The NS proteins include NS2, NS3, NS4, NS4B, NS5A, and NS5B; the structural proteins include the core proteins $(C)$, envelope proteins (E1, E2), and p7 polypeptide (Figure 2) ${ }^{[12,14]}$.

Of the NS proteins, RNA-dependent RNA polymerase, NS5A, and NS3 serine-like protease are involved in HCV maturation and replication. Therefore, these comprise the main target zones in the development of anti-HCV molecules. Direct-acting antiviral agents groups used in HCV treatment and their properties are presented in Table $1^{[15]}$.

\section{NS3/4A Protease Inhibitors (PI)}

NS3/4A PI suppress viral replication by inhibiting NS3/4A serine protease, which has an important role in post-translational processing. Telaprevir and boceprevir are first generation NS3/4A Pls approved for use in combination with pegIFN + R in genotype $1 \mathrm{HCV}$ infection. However, these agents have disadvantages such as adverse effects, lower barriers to resistance, and drug interactions. Furthermore, their clinical importance has been greatly diminished with the development of more potent and tolerable DAAs.

New generation Pls are more effective against genotype 1, and most have limited efficacy against other genotypes ${ }^{[16]}$. Pls cannot be equally effective against all HCV genotypes due to significant genotypic differences in NS3 protease amino acid sequences. Furthermore, this drug group has a relatively lower barrier to resistance.

New generation Pls include grazoprevir, paritaprevir, simeprevir, and asunaprevir. Grazoprevir is a potent pangenotypic PI. It is available as a combination with elbasvir, a NS5A inhibitor. It is a weak inhibitor of CYP3A4. There is no need for dose adjustment in renal disease ${ }^{[17-19]}$.

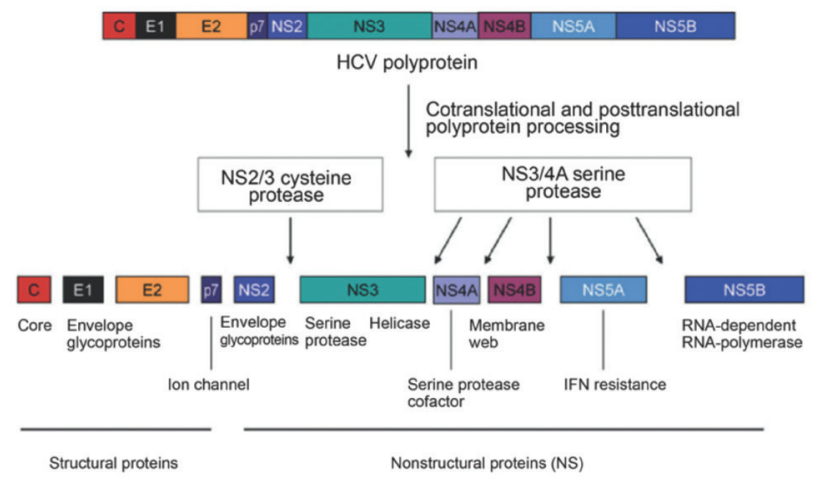

Figure 2. HCV polyprotein and posttranslational polyprotein processing $^{[12,14]}$ 
Table 1. Direct-acting antiviral agents groups used in HCV treatment and their properties ${ }^{[15]}$

\begin{tabular}{|c|c|c|c|c|}
\hline & Protease inhibitors & $\begin{array}{l}\text { Nucleos(t)ide polymerase } \\
\text { inhibitors }\end{array}$ & $\begin{array}{l}\text { Non-nucleos(t)ide } \\
\text { polymerase inhibitors } \\
\text { (dasabuvir) }\end{array}$ & NS5A inhibitors \\
\hline Activity spectrum & GT $1 \mathrm{~b}>\mathrm{GT} 1 \mathrm{a}$ & All genotypes & GT $1 b>1 a$ & All genotypes \\
\hline Efficacy & $\begin{array}{l}\text { High (varies by } \\
\text { genotype) }\end{array}$ & $\begin{array}{l}\text { Medium-high (varies by HCV } \\
\text { genotype and subtype) }\end{array}$ & Varies by HCV genotype & $\begin{array}{l}\text { High (against many } \\
\text { HCV genotypes) }\end{array}$ \\
\hline Barrier to resistance & $\operatorname{Low}(1 \mathrm{a}<1 \mathrm{~b})$ & $\operatorname{High}(1 \mathrm{a}=1 \mathrm{~b})$ & Very low $(1 \mathrm{a}<1 \mathrm{~b})$ & Low $(1 \mathrm{a}<1 \mathrm{~b})$ \\
\hline $\begin{array}{l}\text { Drug interaction } \\
\text { potential }\end{array}$ & High & Low & Variable & Low-moderate \\
\hline Toxicity & $\begin{array}{l}\text { Rash, anemia, } \\
\text { elevated bilirubin }\end{array}$ & $\begin{array}{l}\text { Mitochondrial toxicity, } \\
\text { interaction with antiretroviral } \\
\text { agents (nucleoside reverse } \\
\text { transcriptase inhibitors and } \\
\text { ribavirin) }\end{array}$ & Variable & Variable \\
\hline Dose & $\begin{array}{l}\text { Once daily or in } 3 \\
\text { doses }\end{array}$ & Once daily or in 2 doses & $\begin{array}{l}\text { Once daily or in } 3 \text { doses } \\
\text { dasabuvir twice daily }\end{array}$ & Once daily \\
\hline Drugs & $\begin{array}{l}\text { Boceprevir } \\
\text { Telaprevir } \\
\text { Simeprevir } \\
\text { Paritaprevir } \\
\text { Asunaprevir } \\
\text { Grazoprevir }\end{array}$ & Sofosbuvir & $\begin{array}{l}\text { GS-9669 } \\
\text { Beclabuvir } \\
\text { Dasabuvir }\end{array}$ & $\begin{array}{l}\text { Ledipasvir } \\
\text { Daclatasvir } \\
\text { Ombitasvir } \\
\text { Elbasvir } \\
\text { Velpatasvir }\end{array}$ \\
\hline Explanation & $\begin{array}{l}\text { Next generation Pls } \\
\text { are expected to have } \\
\text { higher barriers to } \\
\text { resistance and be } \\
\text { effective against all } \\
\text { genotypes }\end{array}$ & $\begin{array}{l}\text { Single target for binding to the } \\
\text { active site }\end{array}$ & $\begin{array}{l}\text { Multiple targets for } \\
\text { binding allosteric sites }\end{array}$ & $\begin{array}{l}\text { Multiple mechanisms } \\
\text { of antiviral action }\end{array}$ \\
\hline
\end{tabular}

PI: Protease inhibitors

Paritaprevir is administered with the pharmacologic enhancer ritonavir and in combination with ombitasvir (an NS5A inhibitor). It is commonly used in combination with the NS5B inhibitor dasabuvir if indicated. Dose adjustment is not required in mild/moderate/severe renal disease or mild liver disease. It is not recommended in moderate liver dysfunction (Child-Pugh B) and is contraindicated in patients with severe liver dysfunction (Child-Pugh C) ${ }^{[19]}$.

Simeprevir is the first of the second generation Pls to be used. It is used to treat genotype 1 infections, often in combination with peg-IFN $+R$ or sofosbuvir $\pm R$. A single daily dose of $150 \mathrm{mg}$ is recommended. Dose adjustment is not necessary in patients with renal disease. It is eliminated via the liver. It is not recommended for patients with Child-Pugh grades $B$ and C liver dysfunction due to increased exposure. Simeprevir is metabolized by the CYP3A subfamily. Therefore, it should be noted that simeprevir concentration is altered when used with drugs that significantly increase or decrease CYP3A4.

Many mutations in NS3/4A protease result in reduced sensitivity to simeprevir. The strongest association is with $080 \mathrm{~K}$ polymorphism. In a clinical study, this polymorphism was found in 30\% of patients with genotype 1a infections who were treated with simeprevir + pegIFN + R, and was associated with lower SVR rates (58\% with polymorphism, 84\% without polymorphism) ${ }^{[20]}$. In patients with first generation PI treatment failure, resistance mutations also reduced sensitivity to treatment with simeprevir in vitro. Therefore, these patients are expected to show a low response to simeprevir therapy ${ }^{[21]}$.

Asunaprevir is primarily metabolized by the liver. Liver dysfunction may lead to higher drug concentrations. Dose adjustment is not required for patients with renal failure and undergoing hemodialysis. Drug interactions must be kept in mind. It is generally well tolerated ${ }^{[19]}$.

Second generation Pls are better tolerated than first generation drugs and are taken in fewer tablets. Although barrier to resistance is lower for these drugs, combining them with other antiviral agents substantially reduces development of resistance.

NS5B RNA-dependent RNA Polymerase Inhibitors (RdRp)

NS5B RdRp plays an important role in the HCV replication cycle. This makes it an ideal target for medical treatment. The structure 
of the enzyme is well conserved in all HCV genotypes. There are two classes of NS5B polymerase inhibitors: nucleos(t)ide polymerase inhibitors (NIs) and non-nucleos(t)ide polymerase inhibitors (NNIs).

Nls target the highly conserved active area of NS5B and result in chain termination. Although the development of various NS5B Nls was halted due to their high level of toxicity, some were shown to be more tolerable. These drugs are effective against all $\mathrm{HCV}$ genotypes as well as being equally effective against subtypes $1 \mathrm{a}$ and $1 \mathrm{~b}$. Their resistance barrier is very high. Sofosbuvir is the first approved NS5B NI in this group. This drug is not used as monotherapy but is combined with other antivirals with different indications. Sofosbuvir is taken as a single daily dose of $400 \mathrm{mg}$ with or without food. Sofosbuvir is eliminated via the renal route. Pharmacokinetic studies indicate that reducing the dose or discontinuing the medication is not necessary when glomerular filtration rate (GFR) is over $30 \mathrm{ml} / \mathrm{min}$. Exposure to sofosbuvir and its metabolites is greater in patients with severe renal failure or those undergoing dialysis and is therefore not currently recommended for this patient group. It can be used by patients with cirrhosis (including Child-Pugh B and C). The drug is well tolerated with no major adverse effects. The most common side effects observed in studies of sofosbuvir $+R \pm$ peg-IFN treatment were malaise, headache, nausea, insomnia, and anemia ${ }^{[22]}$. It is not metabolized with hepatic CYP450 enzymes, and thus causes limited drug-drug interactions. There are fewer drug interactions than seen with Pls. It has been well tolerated in the studies performed to date. As it is a substrate of P-glycoprotein (P-gp), drugs that are potent inducers of intestinal P-gp may decrease levels of sofosbuvir. The combined use of sofosbuvir + amiodarone is not recommended due to the potential for symptomatic bradycardia and fatal cardiac arrest ${ }^{[23]}$. Resistance polymorphisms in NS5B polymerase have been reported, although the clinical significance after exposure to sofosbuvir is not known. These polymorphisms are S282T, L159F, and E341D. The S282T polymorphism is particularly is associated with reduced sensitivity to sofosbuvir ${ }^{[24]}$.

NNIs act as allosteric inhibitors that prevent the enzyme from making the structural changes required for extension of the newly formed RNA chain. Non-nucleos(t)ide polymerase inhibitors bind to four allosteric sites: thumb domain 1 and 2 and palm domain 1 and 2. Due to the structure of this interaction, NS5B NNIs are less effective and more susceptible to resistance development than NS5B Nls. This group of drugs is generally used in addition to more potent compounds with higher barriers to resistance. As a group, NNIs are less potent and more genotype-specific. Dasabuvir, a member of this group, is used in combination with ombitasvir-paritaprevir/ritonavir. Dasabuvir must be taken twice daily ${ }^{[15,19]}$.

\section{NS5A Inhibitors}

NS5A inhibitors disrupt the stages of viral replication and accumulation of HCV virus ${ }^{[25]}$. However, it is not clear by what mechanisms they disrupt these functions. These drugs have considerable potency, but low barriers to resistance. Although NS5A inhibitors tend to exhibit pangenotypic activity, their antiviral effects against genotypes other than genotype 1 differ depending on the molecule.

They have variable toxicity profiles. Currently available NS5A inhibitors are ledipasvir, ombitasvir, elbasvir (in combination with other DAAs), and daclatasvir.

Daclatasvir: Generally used in combination with sofosbuvir. It should not be used as monotherapy. It is administered as a single daily dose of $60 \mathrm{mg}$ taken irrespective of meals. Dose adjustment is not needed in patients with renal and liver dysfunction. Although well-tolerated, the most common side effects are mild to moderate headache, malaise, and nausea ${ }^{[26]}$. The drug is primarily metabolized via CYP3A. Therefore, it should not be used with drugs that increase this enzyme. The NS5A protein polymorphisms M28, A30, L31, and Y93 have been associated with in vitro daclatasvir resistance. Mutations in $\mathrm{Y} 93$ have the strongest clinical association with resistance. In a study including 148 patients infected with genotype 3 and receiving treatment with sofosbuvir + daclatasvir, 13 patients were found to have baseline $\mathrm{Y} 93 \mathrm{H}$ polymorphism and exhibited lower $\mathrm{SVR}^{[27]}$. Of the 10 patients without baseline $\mathrm{Y} 93 \mathrm{H}$ polymorphism that showed virologic failure, 9 were found to have developed $\mathrm{Y} 93 \mathrm{H}$ polymorphism. Other polymorphisms were not associated with clinical response.

\section{Fixed Dose Combinations}

\section{Grazoprevir/Elbasvir}

Grazoprevir is a NS3/4A PI with high barrier to resistance, and elbasvir is a NS5A inhibitor. A single tablet contains 100 $\mathrm{mg}$ grazoprevir combined with $50 \mathrm{mg}$ elbasvir. It is taken as a single daily dose with or without food. Before use, patients with genotype 1a infection must be tested for NS5A resistance, and baseline aminotransferase levels should be checked in all patients. While grazoprevir/elbasvir can be given safely to dialysis patients, it is contraindicated in patients with Pugh B and C cirrhosis. The drug is well-tolerated and the most common side effects reported in clinical trials have been headache, malaise, and nausea ${ }^{[28,29]}$. Severe adverse events are rare and occur at similar rates to placebo. Approximately $\% 1$ of patients had aminotransferase levels 5 times higher than the normal upper limits without bilirubin elevation, and these values decreased to normal levels when treatment was discontinued. Therefore, aminotransferase monitoring is recommended at baseline and at 
8 and 12 weeks of treatment. Treatment should be discontinued if ALT elevation is accompanied by elevated bilirubin and INR. This combination is primarily metabolized via CYP3A. The drug must not be used with others that strongly induce or inhibit this enzyme. Grazoprevir is a substrate of OATP1B1/3 and should not be given together with drugs that inhibit this enzyme.

Baseline NS5A polymorphisms at M28, Q30, L31, and Y93 are associated with elbasvir resistance and with reduced SVR with combined grazoprevir/elbasvir in patients with subtype 1a infections ${ }^{[28]}$. These polymorphisms are believed to be present in about $11 \%$ of subtype 1a. Therefore, the patients infected with subtype1a should be tested for these polymorphisms before initiating grazoprevir/elbasvir. If any of these polymorphisms are detected, SVR can be increased by adding $R$ to the treatment or by extending the treatment duration ${ }^{[28]}$. In contrast, these polymorphisms do not seem to affect SVR in patients with genotype $1 b$.

The list of amino acid substitutions that have been associated with reduced sensitivity and resistance (resistance-associated substitutions; RASs) in different HCV genotypes and subtypes for different DAAs is shown in Table $2^{[30]}$.

\section{Sofosbuvir/Ledipasvir}

Nucleotide polymerase inhibitor sofosbuvir and NS5A inhibitor ledipasvir have been co-formulated in a single tablet. The combination contains $400 \mathrm{mg}$ of sofosbuvir and $90 \mathrm{mg}$ of ledipasvir. The drug is taken once daily with or without food. Although ledipasvir's pharmacokinetics is not influenced in severe renal failure, sofosbuvir and its metabolites accumulate. Combination therapy should not be used by patients with severe renal failure until further data are available. However, it can be used by patients with mild to moderate renal disease and moderate (Child-Pugh B) to severe (Child-Pugh C) liver dysfunction with no dosage adjustment. This combination is well tolerated, with mild to moderate fatigue, headache, nausea, and insomnia being the most commonly reported side effects. Like sofosbuvir, ledipasvir is also a substrate of P-gps. Therefore, intestinal P-gp inducers may reduce levels of ledipasvir. Similarly, increased gastric $\mathrm{pH}$ levels may also reduce levels of ledipasvir. This should be considered if the two must be used together. Drugs that are not used with sofosbuvir should also not be used with this combination. Virologic failure with sofosbuvir/ledipasvir may occur due to NS5A mutations that reduce sensitivity to ledipasvir. The most common of these are $030 \mathrm{R}, \mathrm{Y} 93 \mathrm{H} / \mathrm{N}$, and L31M in subtype 1a and Y93H in subtype $1 b^{[31,32]}$.

\section{Ombitasvir + Paritaprevir/Ritonavir \pm Dasabuvir $(\mathrm{OBV} / \mathrm{PTV} / \mathrm{r}$, DSV)}

The NS5A inhibitor ombitasvir has been formulated together with the Pls paritaprevir and ritonavir. In Turkey it is commercially available in a single pack for OBV/PTV/r and a separate pack for dasabuvir.

Ritonavir does not exhibit direct anti-HCV activity, but inhibits the CYP3A-mediated metabolism of paritaprevir and increases its concentration. Patients with genotype 1 infection are treated with OBV/PTV/r + DSV with or without $R$ depending on the patient population, while patients with genotype 4 infection are given OBV/PTV/r with R. OBV/PTV/r (12.5/75/50 mg tablet) is taken once daily with food. Dasabuvir as part of the regimen is taken as a $250 \mathrm{mg}$ tablet twice daily. Although dose adjustment is not required in renal disease, this therapy is not recommended for patients with moderate/severe liver dysfunction. It is generally well tolerated with mild side effects. Decompensation has been reported in patients with cirrhosis. Adverse effects

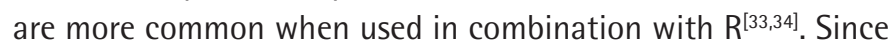
the components of this combination are both substrates and inhibitors of major metabolic enzymes (CYP2C8, CYP3A), the potential for drug interactions must be kept in mind. Exposure to OBV/PTV/r and DSV may select for mutations in NS3, NS5A, and NS5B, which may reduce the activities of the drugs. In clinical studies, the mutations that most commonly appear during treatment or in relapsed patients with subtype 1a infection are D168V in NS3, M28A/T/N and 080E/K/R in NS5A, and S556G/R in $\mathrm{NS}_{5} \mathrm{~B}^{[30,33,35]}$. Virologic failure is rare in subtype $1 \mathrm{~b}$ infections. Although the prevalence of some baseline resistance-associated mutations was found to be significantly higher in patients whose treatment failed compared to those who achieved SVR, these were shown to be clinically insignificant or have no prognostic value in relation to treatment.

\section{Sofosbuvir + Velpatasvir}

Pangenotypic NS5A inhibitor velpatasvir and NS5B inhibitor sofosbuvir have been co-formulated in a single tablet. The tablet contains $100 \mathrm{mg}$ velpatasvir and $400 \mathrm{mg}$ sofosbuvir and is taken once daily with or without food. It can be used by patients with mild to moderate renal disease and moderate to severe liver dysfunction (Child-Pugh B and C). Studies have shown that the pharmacokinetics of velpatasvir is not affected by severe renal failure (GFR $<30 \mathrm{ml} / \mathrm{min} / 1.73 \mathrm{~m}^{2}$ ), whereas levels of sofosbuvir and its metabolites increase. Therefore, this combination should not be used with patients with severe renal failure until further data are available ${ }^{[36]}$.

The drug is well tolerated and the frequency of adverse effects is similar to that in placebo. The most common side effects are headache, malaise, nausea, nasopharyngitis, and insomnia. Like sofosbuvir, velpatasvir is also a substrate of P-gp. Therefore inducers of intestinal P-gp may reduce levels of velpatasvir. Virologic failure has been associated with $\mathrm{Y} 93 \mathrm{~N} / \mathrm{H}$ mutations arising in the NS5A gene in genotypes 1 and 3 . It is reported that the baseline mutations in genotype 3 (particularly $\mathrm{Y} 93 \mathrm{H}$ ) 
Table 2. Amino acid substitutions associated with reduced sensitivity and resistance (resistance-associated substitutions, RASs) for different direct-acting antivirals in different HCV genotypes and subtypes ${ }^{[30]}$

\begin{tabular}{|c|c|c|c|c|c|c|c|}
\hline \multirow[t]{2}{*}{ Drug group } & \multicolumn{7}{|l|}{ Genotype/subtype } \\
\hline & $1 \mathrm{a}$ & $1 b$ & 2 & 3 & 4 & 5 & 6 \\
\hline $\begin{array}{l}\text { Nucleotide analog } \\
\text { (sofosbuvir) }\end{array}$ & $\begin{array}{l}\text { L159F } \\
\text { S282T/R } \\
\text { L320I/F/N } \\
\text { V321A }\end{array}$ & $\begin{array}{l}\mathrm{L} 159 \mathrm{~F} \\
\text { S282T }\end{array}$ & $\begin{array}{l}\text { L159F } \\
\text { S282T }\end{array}$ & $\begin{array}{l}\text { L159F } \\
\text { S282T } \\
\text { V321A }\end{array}$ & S282T & S282T & \\
\hline $\begin{array}{l}\text { NS5A } \\
\text { inhibitors }\end{array}$ & $\begin{array}{l}\mathrm{K} 24 \mathrm{G} / \mathrm{N} / \mathrm{R} \\
\mathrm{K} 26 \mathrm{E} \\
\mathrm{M} 28 \mathrm{~A} / \mathrm{G} / \mathrm{T} / \mathrm{S} / \mathrm{N}^{*} \\
\mathrm{O} 30 \mathrm{C} / \mathrm{D} / \mathrm{E} / \mathrm{G} / \mathrm{H} / \mathrm{I} / \mathrm{K} / \mathrm{L} / \mathrm{Q} / \mathrm{R} / \mathrm{S} / \mathrm{T} / \mathrm{Y}^{*} \\
\mathrm{~L} 31 \mathrm{I} / \mathrm{F} / \mathrm{M} / \mathrm{P} / \mathrm{N}^{*} \\
\mathrm{P} 32 \mathrm{~L} / \mathrm{S}^{*} \\
\mathrm{~S} 38 \mathrm{~F} \\
\mathrm{H} 58 \mathrm{D} / \mathrm{L} / \mathrm{R}^{*} \\
\mathrm{~A} 92 \mathrm{~K} / \mathrm{T} \\
\mathrm{Y} 93 \mathrm{C} / \mathrm{F} / \mathrm{H} / \mathrm{L} / \mathrm{N} / \mathrm{R} / \mathrm{S} / \mathrm{T} / \mathrm{W}^{*}\end{array}$ & $\begin{array}{l}\mathrm{L}^{28 M} / \mathrm{T}^{*} \\
\mathrm{P} 29 \mathrm{~S} \\
\text { R30G/H/P/O/R } \\
\text { L31F/I/M/N* } \\
\text { P32F/L/S } \\
\text { P58D/S* } \\
\text { O/E62D } \\
\text { A92K } \\
\text { Y93C/H/N/S* }\end{array}$ & $\begin{array}{l}\text { T24A } \\
\text { L/F28M/V/S* } \\
\text { L30H/S } \\
\text { L31M/N* } \\
\text { Y93H }\end{array}$ & $\begin{array}{l}\text { M28T } \\
\text { A30K/S } \\
\text { L311/M/N* } \\
\text { Y93H }\end{array}$ & $\begin{array}{l}\text { L28S/N } \\
\text { L30H } \\
\text { L311/M* } \\
\text { T58P/S } \\
\text { Y93H/R }\end{array}$ & $\begin{array}{l}\mathrm{L} 28 \mathrm{I} \\
\mathrm{L} 31 \mathrm{~V}^{*}\end{array}$ & $\begin{array}{l}\text { 024H } \\
\text { F28L } \\
\text { L31M/N* } \\
\text { P32L/S } \\
\text { T58A/N/S } \\
\text { V36I }\end{array}$ \\
\hline Protease inhibitors & $\begin{array}{l}\text { V36A/C/G/L/M } \\
\text { O41R } \\
\text { F43L } \\
\text { T54A/S } \\
\text { V55A/I } \\
\text { Y56H } \\
\text { 080H/K/L/R } \\
\text { S122G/R } \\
\text { R155G/I/K/M/S/T/W } \\
\text { A156S/T/N* } \\
\text { V158I } \\
\text { D168A/C/E/F/G/H/I/K/L/N/T/N/Y* } \\
\text { I/V170F/T/N }\end{array}$ & $\begin{array}{l}\text { V36A/C/G/L/M } \\
\text { 041R } \\
\text { F43I/S/N } \\
\text { T54A/C/G/S } \\
\text { V55A } \\
\text { Y56H/L } \\
\text { 080H/K/L/R } \\
\text { S122D/G/I/N/R/T } \\
\text { R155C/G/I/K/O/M/S/T/W } \\
\text { A156G/F/S/T/N* } \\
\text { V158I } \\
\text { D168A/C/E/F/G/H/I/K/L/N/T/V/Y* } \\
\text { IN170A/L/T } \\
\text { M175L }\end{array}$ & Y56H & 0168R & $\begin{array}{l}\text { Y56H } \\
\text { D168V* }\end{array}$ & & $\begin{array}{l}\text { Y56H } \\
\text { L80K/0 } \\
\text { S122T } \\
\text { D168E/Y* } \\
\text { I170V }\end{array}$ \\
\hline $\begin{array}{l}\text { Nonnucleoside } \\
\text { palm-1 inhibitor } \\
\text { (dasabuvir) }\end{array}$ & 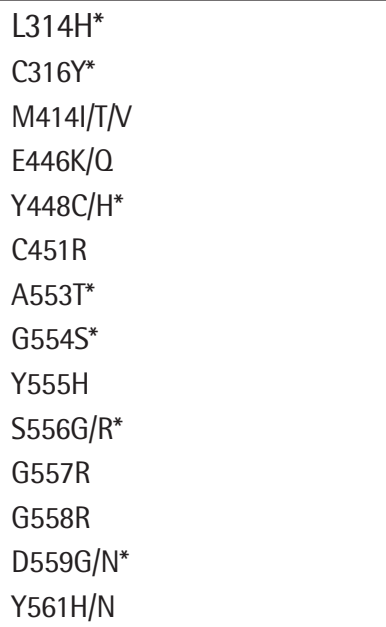 & $\begin{array}{l}\mathrm{C} 316 \mathrm{H} / \mathrm{N} / \mathrm{Y} / \mathrm{W}^{*} \\
\mathrm{~S} 368 \mathrm{~T}^{*} \\
\mathrm{~N} 411 \mathrm{~S} \\
\mathrm{M} 414 \mathrm{I} / \mathrm{T} / \mathrm{V} \\
\mathrm{C} 445 \mathrm{~F} / \mathrm{Y} \\
\mathrm{Y} 448 \mathrm{C} / \mathrm{H}^{*} \\
\text { A553V* } \\
\text { G554S* } \\
\text { S556G/R } \\
\text { G558R } \\
\text { D559G/N* }\end{array}$ & & & & & \\
\hline
\end{tabular}

*Resistance-associated substitutions associated with high-level resistance in a replicon model 
may be more associated with relapse. High rates of SVR were observed even in the presence of these mutants (88\% in patients with mutation and $97 \%$ in others ${ }^{[36]}$.

\section{Glecaprevir/Pibrentasvir}

The fixed dose tablet contains $100 \mathrm{mg}$ of the NS3/4A inhibitor glecaprevir and $40 \mathrm{mg}$ of the NS5A inhibitor pibrentasvir and is taken as a single dose 3 times daily. This is one of the combinations preferred for treatment-naive and treatmentexperienced patients with genotype 1 and/or in patients with compensated cirrhosis. The drug can also be given to patients with renal failure. The other new regimens approved for severe renal failure include only genotype 1 and 4. Glecaprevir/ pibrentasvir is particularly important in terms of offering a treatment option without $\mathrm{R}$ to chronic $\mathrm{HCV}$ patients with end stage renal failure infected with genotypes $2,3,5$, and 6 .

Recommended treatment duration for this combination is 8 weeks for non-cirrhotic patients without NS3/4A or NS5A inhibitor treatment experience and 12 weeks for cirrhotic patients ${ }^{[37-39]}$. Treatment for 12 weeks is recommended for patients with NS3/4A inhibitor experience and 16 weeks in patients with NS5A inhibitor experience ${ }^{[40]}$.

The drug is well tolerated. The most common side effects are headache and malaise ${ }^{[41,42]}$. Rarely, aminotransferase and bilirubin may be elevated. It should not be used with rifampin, atazanavir, oral contraceptives, carbamazepine, or cyclosporine. Amino acid substitutions at A156 and to a lesser extent D/ 0168 are associated with reduced sensitivity to glecaprevir in genotypes $1 a, 1 b, 2,3,4$, and 6 . However, these mutations are rare in clinical practice ${ }^{[43]}$.

\section{Sofosbuvir/Velpatasvir/Voxilaprevir}

The NS5B inhibitor sofosbuvir, NS5A inhibitor velpatasvir, and NS3/4A PI voxilaprevir comprise a fixed dose combination taken once daily. It has pangenotypic efficacy. It is an effective option in NS5A inhibitor-naive patients with genotype 1a infection with prior failure of treatment including sofosbuvir. Treatment duration is 12 weeks in this patient subgroup. With this combination, the rate of SVR in patients previously treated with NS5A inhibitors was $96 \%$ in genotype $1 \mathrm{a}$ and $100 \%$ in genotype $1 b^{[44]}$. Although many patients exhibited baseline NS3/4A and NS5A amino acid substitutions, they did not have reduced SVR rates ${ }^{[44]}$.

Adding $\mathrm{R}$ to the treatment regimen for cirrhotic patients did not affect outcomes ${ }^{[45]}$. In a study comparing sofosbuvir/velpatasvir/ voxilaprevir and sofosbuvir/velpatasvir in NS5A inhibitor-naive patients with prior treatment failure with a sofosbuvir-based regimen, SVR rate was higher in genotype 1a patients receiving triple treatment ( $98 \%$ and $89 \%$, respectively). The rates did not differ significantly in patients with genotype $1 \mathrm{~b}$ infection (96\% and $95 \%$, respectively $)^{[44]}$.
The most common adverse effects of the drug are headache, malaise, diarrhea, and nausea. While its use with rifampin is contraindicated, it is not recommended for use with amiodarone, St John's wort, anticonvulsants, some antiretrovirals, and cyclosporine.

Information concerning all of the aforementioned treatment regimens and potential drug interactions are available at https:// www.hep-druginteractions.org/.

Major clinical phase trials of the DAAs used in HCV infection and the sources cited in these studies are given in Table $3^{[36,37,39,44,46-}$ ${ }^{72]}$.

Table 3. Important clinical trials of direct-acting antiviral agents used in HCV infection and their sources

\begin{tabular}{|c|c|c|}
\hline Drug & Study name & Source \\
\hline Sofosbuvir + ledipasvir & $\begin{array}{c}\text { ION I } \\
\text { ION II } \\
\text { ION III } \\
\text { Eradicate } \\
\text { SOLAR } \\
\text { Cirrhosis } 500\end{array}$ & $\begin{array}{l}46 \\
47 \\
48 \\
49 \\
50 \\
51\end{array}$ \\
\hline $\begin{array}{l}\text { Paritaprevir/ritonavir ombitasvir } \\
\text { dasabuvir }\end{array}$ & $\begin{array}{c}\text { Sapphire I } \\
\text { Sapphire II } \\
\text { Turquase II } \\
\text { Turquase III } \\
\text { Pearl II } \\
\text { Pearl III } \\
\text { Pearl IV }\end{array}$ & $\begin{array}{l}52 \\
53 \\
54 \\
55 \\
56 \\
57 \\
57\end{array}$ \\
\hline Sofosbuvir + simeprevir & cosMOS & 58 \\
\hline $\begin{array}{l}\text { Daclatasvir + asunaprevir + } \\
\text { beclabuvir }\end{array}$ & $\begin{array}{l}\text { UNITY I } \\
\text { UNITY II }\end{array}$ & $\begin{array}{l}59 \\
59\end{array}$ \\
\hline Grazoprevir + elbasvir & $\begin{array}{c}\text { C-EDGE } \\
\text { C-Salvage } \\
\text { C-WORTHY } \\
\text { C-EDGE TE }\end{array}$ & $\begin{array}{l}60 \\
61 \\
62 \\
63\end{array}$ \\
\hline Glecaprevir + pibrentasvir & $\begin{array}{l}\text { ENDURANCE } 1 \\
\text { ENDURANCE } 2 \\
\text { ENDURANCE } 3 \\
\text { ENDURANCE } 4 \\
\text { SURVEYOR } 1 \\
\text { SURVEYOR } 2 \\
\text { EXPEDITION } 1 \\
\text { EXPEDITION } 2\end{array}$ & $\begin{array}{l}35 \\
64 \\
65 \\
66 \\
67 \\
68 \\
39 \\
69\end{array}$ \\
\hline Sofosbuvir + velpatasvir & $\begin{array}{c}\text { ASTRAL } 1 \\
\text { ASTRAL } 2 \\
\text { ASTRAL } 3 \\
\text { POLARIS } 2 \\
\text { POLARIS } 3\end{array}$ & $\begin{array}{l}36 \\
70 \\
71 \\
72\end{array}$ \\
\hline $\begin{array}{l}\text { Sofosbuvir + velpatasvir + } \\
\text { voxilaprevir }\end{array}$ & POLARIS 4 & 44 \\
\hline
\end{tabular}


Table 4. Drugs approved internationally and in Turkey for the treatment of hepatitis $\mathrm{C}^{[73]}$

\begin{tabular}{l|l|l|l}
\hline Drug & Contents & Usage & Approved in Turkey \\
\hline Sovaldi & Sofosbuvir $400 \mathrm{mg}$ & Once daily (morning) & $*$ \\
\hline Harvoni & Sofosbuvir $400 \mathrm{mg}+$ ledipasvir $90 \mathrm{mg}$ & Once daily (morning) & $*$ \\
\hline Viekirax & Paritaprevir $75 \mathrm{mg}+$ ritonavir $50 \mathrm{mg}+$ ombitasvir $12.5 \mathrm{mg}$ & Two tablets once daily (morning) & $*$ \\
\hline Exviera & Dasabuvir $250 \mathrm{mg}$ & Twice daily (morning, evening) & $*$ \\
\hline Epclusa & Sofosbuvir $400 \mathrm{mg}+$ velpatasvir $100 \mathrm{mg}$ & Once daily (morning) & \\
\hline Zepatier & Grazoprevir $100 \mathrm{mg}+$ elbasvir $50 \mathrm{mg}$ & Once daily (morning) & \\
\hline Daklinza & Daclatasvir $30 \mathrm{mg}$ or $60 \mathrm{mg}$ & Once daily (morning) & $*$ \\
\hline Olysio & Simeprevir $150 \mathrm{mg}$ & Once daily (morning) & $*$ \\
\hline Sunvepra ${ }^{\text {a }}$ & Asunaprevir $100 \mathrm{mg}$ & Twice daily (morning, evening) & $*$ \\
\hline
\end{tabular}

a: Not approved by the FDA or EMEA. Approved in Japan, Canada, and Australia

Hepatitis C treatments approved throughout the world and in Turkey are listed in Table $4^{[73]}$.

\section{Who Should Be Treated?}

All patients with proven chronic $\mathrm{HCV}$ infection (those with detectable HCV RNA level for longer than six months) should be treated. Treatment regimen should be selected based on virus genotype and patient factors (e.g.: cirrhosis, previous treatment history).

\section{Monitoring Antiviral Treatment}

\section{Viral Load Monitoring}

Viral load is monitored during DAA therapy to evaluate adherence to the treatment regimen, document the course of treatment, determine virologic response in relapse patients, and make decisions regarding retreatment. Considering that the drugs are expensive and their improper use creates potential risk for resistance, quantitative HCV RNA analysis after 4 weeks is appropriate in clinical practice. According to the IDSA and AASLD guidelines, if HCV RNA is positive at 4 weeks, it should be reevaluated at 6 weeks, and the treatment discontinued if HCV RNA level has increased more than $1 \log ^{[74]}$. The clinical significance of evaluating viral load at the end of the treatment has not been determined. Furthermore, although not recommended by some specialists, virologic response is generally reevaluated at 12 weeks after treatment.

Other monitoring: Although drug toxicity is rare in DAA therapy, laboratory tests (complete blood count, creatinine, liver enzymes, bilirubin levels) should be done at baseline and again after 4 weeks of treatment.

\section{Follow-up with Grazoprevir/Elbasvir}

In addition to the above, liver enzymes and bilirubin levels should be checked in week 8 of treatment and also in week 12 for treatment durations of 16 weeks. Treatment should be discontinued if ALT is increased more than 10 times baseline level or hyperbilirubinemia is present.

\section{Follow-up with Paritaprevir/Ritonavir + Ombitasvir}

Patients with compensated cirrhosis should be followed closely throughout treatment for hepatic decompensation. This follow-up should include clinical evaluation for findings of hepatic decompensation as well as testing liver enzyme and bilirubin levels in weeks 2, 4, 12, and 24. Treatment should be discontinued in the presence of clinical findings or elevation of these parameters.

\section{Follow-up for Regimens Including Ribavirin}

Complete blood count analysis should be done in weeks 4,8 , and 12 to monitor for anemia and $\mathrm{R}$ dose should be adjusted in cases of anemia ${ }^{[75]}$.

\section{Follow-up of Patients with HBV Coinfection}

Patients with previously untreated or new HBV infection require special caution due to the risk of HBV reactivation during the $\mathrm{HCV}$ treatment. For HBsAg positive patients, HBV DNA levels should be monitored during HCV treatment, and HBV treatment should be initiated if the relevant treatment criteria are met. Two approaches can be taken if the HBV infection does not meet treatment criteria (i.e. HBV DNA levels are low or undetectable): either prophylaxis is initiated and continued for 12 weeks after completion of DAA therapy for HCV infection, or HBV DNA level is monitored regularly (usually every 4 weeks) during and after HCV treatment. Antiviral therapy for HBV is initiated when HBV DNA increases more than 10 times baseline level or previously undetectable HBV DNA level rises above $1000 \mathrm{IU} / \mathrm{ml}$. There are no definitive data regarding follow-up of patients who are HBsAg negative but anti-HBs positive. It is currently recommended to monitor liver enzymes at 4-week intervals during HCV treatment. In cases of unexplainably high enzyme levels during or after HCV treatment, $\mathrm{HBsAg}$ and HBV DNA should be reevaluated ${ }^{[75]}$.

\section{Follow-up After Treatment}

Viral load should be evaluated 12 weeks after the end of treatment. It has been reported that less than $1 \%$ of patients 
experience relapse 12-24 weeks after the treatment, some of which are reinfections rather than true relapses ${ }^{[76,77]}$. Therefore, some specialists recommend monitoring HCV RNA at 24 weeks to confirm continued SVR. Although SVR indicates that the HCV infection is cured, it does not provide HCV immunity, and patients are at risk of reinfection with future exposure. Patients without bridging necrosis or cirrhosis who achieve SVR do not require specific monitoring for HCV infection. In patients who do not achieve SVR, monitoring should continue to evaluate for signs of progressive liver disease and retreatment of HCV infection. Patients with severe fibrosis and cirrhosis should be monitored continuously regardless of SVR achievement. Because these are risk groups for hepatocellular cancer and other complications.

\section{Treatment Selection}

Although current international guidelines recommend patientbased selection of IFN-free DAA treatment regimens for HCV infection, this review is based on information obtained from the 2017 Turkish Guideline for the Diagnosis and Treatment of Viral Hepatitis ${ }^{[73]}$. Moreover, every country has its own priorities concerning antivirals to be used in treatment based on their reimbursement terms. Currently the DAA regimens used/ reimbursed (with treatment schedule and duration adjusted according to genotype, cirrhosis, and treatment history) are combinations of sofosbuvir $+R$, sofosbuvir/ledipasvir, and paritaprevir/ritonavir + ombitasvir \pm dasabuvir $\pm R$ in Turkey. These treatment schemes are constantly updated when needed and as circumstances allow.
Treatment-naive Patients with Genotype 1 Infection, Without Cirrhosis or with Compensated Cirrhosis (Algorithm 1) ${ }^{[78]}$

\section{Sofosbuvir/Ledipasvir}

Treatment duration varies depending on the viral load and presence of cirrhosis. It is usually 8 weeks in non-cirrhotic patients with a viral load less than 6 million IU $/ \mathrm{ml}$. This duration should be extended to 12 weeks in patients that meet these criteria but have negative predictive factors (such as being male or black) or are HIV-positive. Recommended treatment duration for patients who have cirrhosis or viral load over 6 million IU/ $\mathrm{ml}$ is 12 weeks. In both cirrhotic and non-cirrhotic patients, this regimen yields SVR rates over $95 \%{ }^{[79,80]}$.

\section{Paritaprevir/Ritonavir + Ombitasvir + Dasabuvir (OBV/PTV/r, DSV)}

In this group of patients, the treatment duration and inclusion of $R$ depend on the virus subtype and presence of cirrhosis. Treatment including $R$ is recommended for 12 weeks for noncirrhotic patients with subtype 1a infection and 24 weeks for cirrhotic patients with subtype 1a infection. Patients infected with subtype 16 should be treated for 12 weeks regardless of the presence of cirrhosis. Close monitoring for hepatic decompensation is advised if this treatment is given to cirrhotic patients. This treatment regimen is contraindicated in ChildPugh B and C liver dysfunction. Sustained virologic response rates are over $95 \%$, with higher rates in patients infected with subtype $1 b(99-100 \%)^{[33]}$.

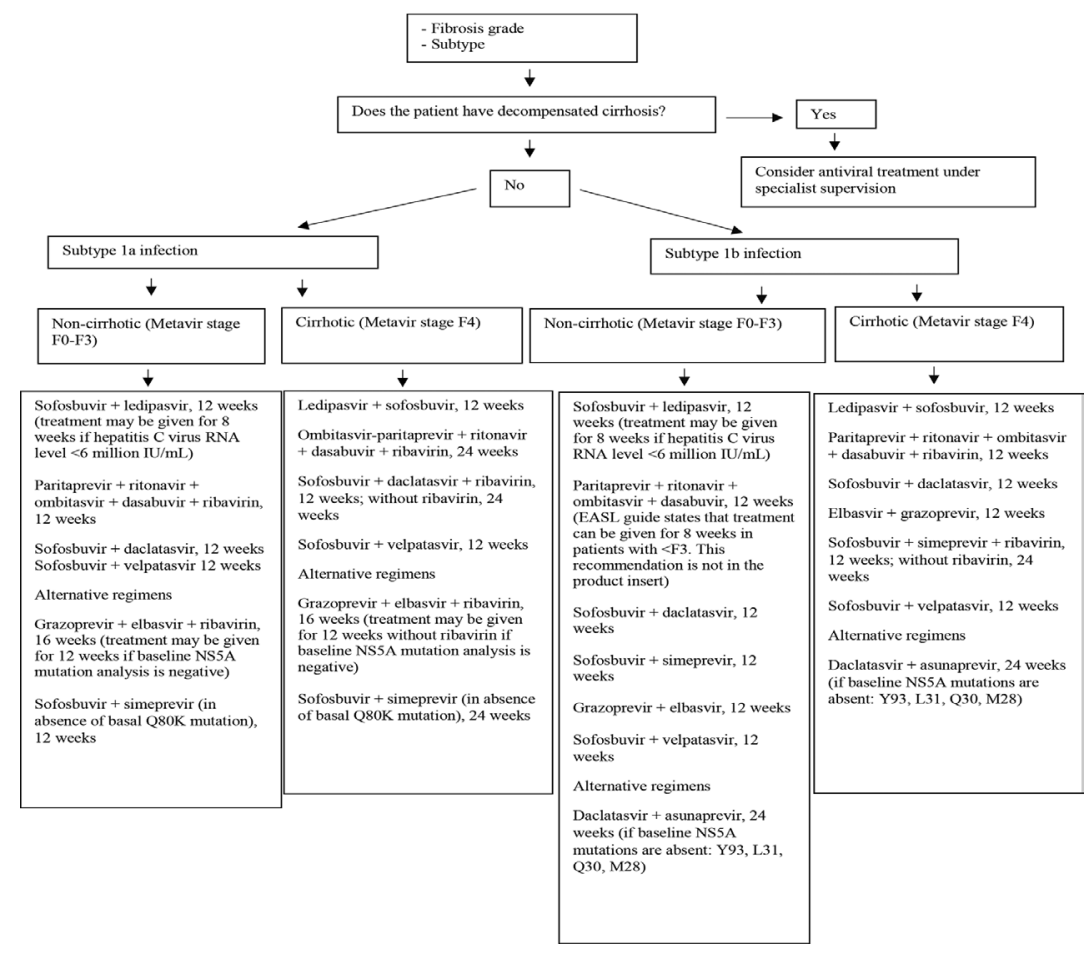

Algorithm 1. Antiviral treatment options for treatment-naive patients with hepatitis $C$ virus genotype 1 infection ${ }^{[7,78]}$ 


\section{Daclatasvir/Sofosbuvir}

This combination is not approved by the FDA for use in genotype 1 infections in America. It is currently in use in other countries. It is administered to non-cirrhotic patients for a period of 12 weeks. The optimal treatment duration is unknown for the cirrhotic genotype 1a patients. AASLD/IDSA guidelines recommended treatment $\pm R$ for a period of 24 weeks. The European Association for the Study of the Liver (EASL) guideline recommends treatment for 12 weeks with $\mathrm{R}$ and 24 weeks without $R^{[81]}$. Turkish guidelines offer similar recommendations to that in the EASL guideline ${ }^{[73]}$. Treatment duration is 12 weeks for cirrhotic patients infected with subtype $1 \mathrm{~b}$.

\section{Sofosbuvir/Velpatasvir}

The recommended treatment duration is 12 weeks. Treatment duration does not depend on the presence of cirrhosis. Sustained virologic response rate is reported to be $98-99 \%{ }^{[36]}$.

\section{Grazoprevir/Elbasvir}

Treatment duration and the addition of $\mathrm{R}$ (weight-based dosing) are determined based on viral subtype and the presence of NS5A resistance-associated variants (RAVs). Patients infected with subtype 1a should be tested for the presence of NS5A RAVs before treatment. Recommended treatment duration is 12 weeks in the absence of RAVs and 16 weeks with $\mathrm{R}$ in the presence of RAVs. In subtype $1 \mathrm{~b}$ infections, treatment does not include $\mathrm{R}$ and lasts 12 weeks. Treatment duration is not dependent on the presence of cirrhosis. Sustained virologic response rate is reported to be above $95 \%{ }^{[28]}$. This regimen is contraindicated in Child-Pugh B and C liver dysfunction.

\section{Sofosbuvir/Simeprevir}

Treatment duration is 12 weeks for non-cirrhotic cases and 24 weeks for cirrhotic cases. Cirrhotic subtype 1a patients should be evaluated for Q80K polymorphism and treatment should be

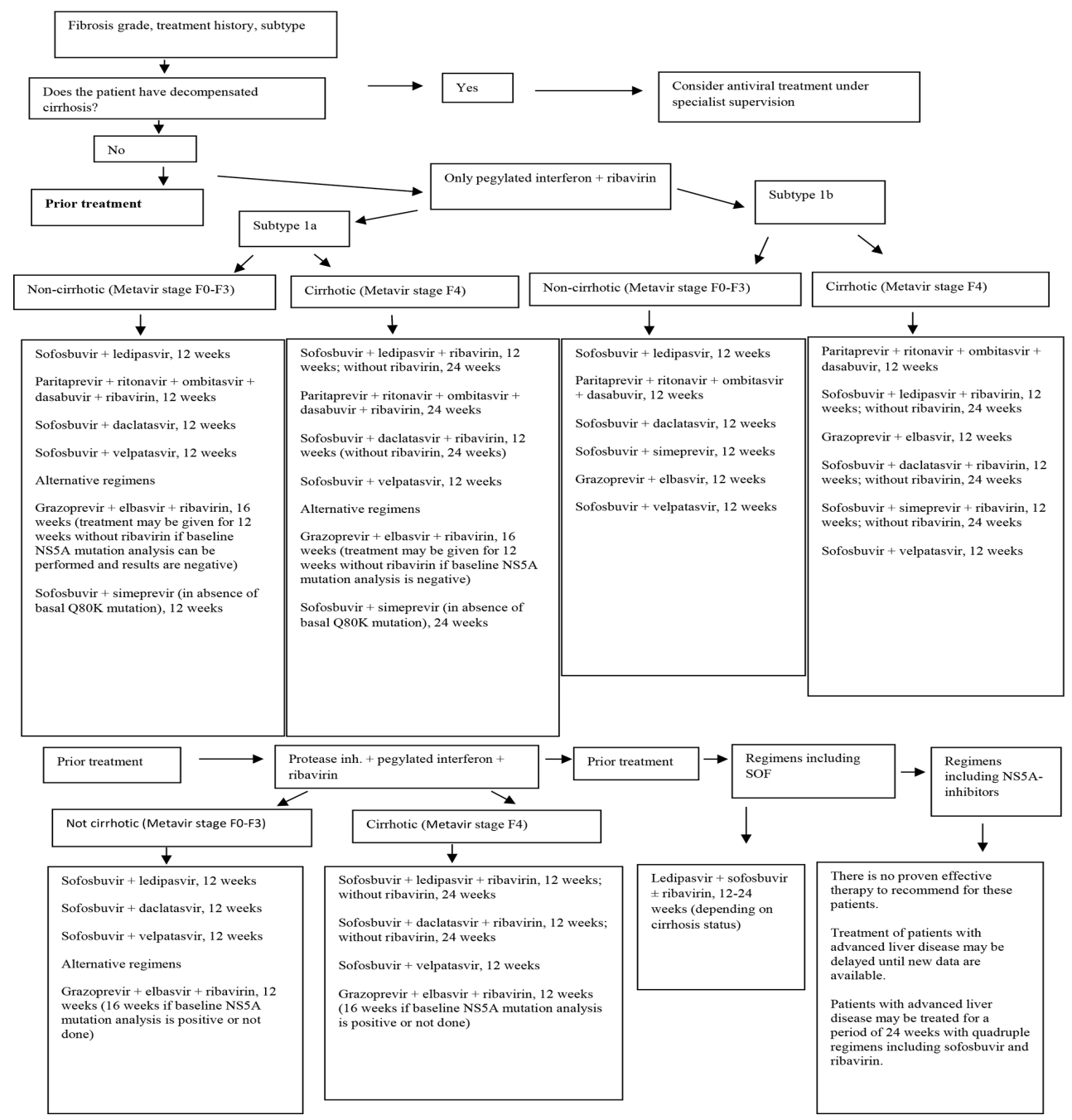

Algorithm 2. Selection of antiviral treatment in treatment-experienced patients with hepatitis $C$ virus genotype 1 infection ${ }^{[73,78]}$ 
changed if positive. Simeprevir should not be used in ChildPugh $B$ and $C$ liver dysfunction. The effect of adding $R$ to this treatment has not been clearly established. Sustained virologic response rate with this treatment is reported to be about $90 \%{ }^{[56]}$.

Treatment-experienced Patients Infected with Genotype 1 (Algorithm 2) $^{[78]}$

\section{Failed Treatment with Peg-IFN $+R$}

Options are the same as in treatment-naive patients.

\section{Failed Treatment with Protease Inhibitors}

For patients with failed prior treatment with simeprevir, boceprevir, or telaprevir + peg-IFN + R:

Sofosbuvir/ledipasvir: Twelve weeks is recommended for patients without cirrhosis; 12 weeks with $\mathrm{R}$ and 24 weeks without $R$ is recommended for patients with compensated cirrhosis. SVR rate with this regimen is $96-100 \% 0^{[41,82]}$.

Daclatasvir/sofosbuvir: Recommended for 12 weeks for patients without cirrhosis; 12 weeks with $R$ and 24 weeks without $R$ for patients with cirrhosis.

Sofosbuvir/velpatasvir: Recommended treatment duration is 12 weeks for this subgroup regardless of the presence of cirrhosis.

Grazoprevir/elbasvir + R: It is effective in patients with prior failed $\mathrm{PI}$ treatment ${ }^{[83]}$. Although grazoprevir is a $\mathrm{Pl}$, it has a very high resistance threshold. Treatment duration of 12 weeks is recommended for this population. Patients with subtype 1a infection should be tested for RAVs due to concerns of reduced efficacy with baseline NS5A RAVs. Treatment duration should be 16 weeks if RAV is detected or cannot be assessed. Other Pls (paritaprevir, simeprevir) are not recommended in patients with prior PI failure. Therefore, the OBV/PTV/r + DSV and sofosbuvir + simeprevir regimens cannot be used.

- Failed Treatment with Sofosbuvir + peg-IFN + R (Without Exposure to NS5A)

These patients should be given sofosbuvir/ledipasvir $\pm R$ for 12 24 weeks, depending on the presence of cirrhosis.

\section{- Failed Treatment with NS5A-inhibitor Regimens}

There is no proven effective therapy to recommend for this patient subgroup. Treatment of patients with advanced liver disease may be delayed until new data are available. Patients with advanced liver disease may be treated for a period of 24 weeks with quadruple regimens including sofosbuvir and $\mathrm{R}$.

Treatment-naive or peg-IFN + R-Experienced Patients Infected with Genotype 2 (Algorithm 3) ${ }^{[84]}$

Sofosbuvir + daclatasvir or sofosbuvir/velpatasvir may be given for 12 weeks, regardless of the presence of cirrhosis ${ }^{[26]}$.

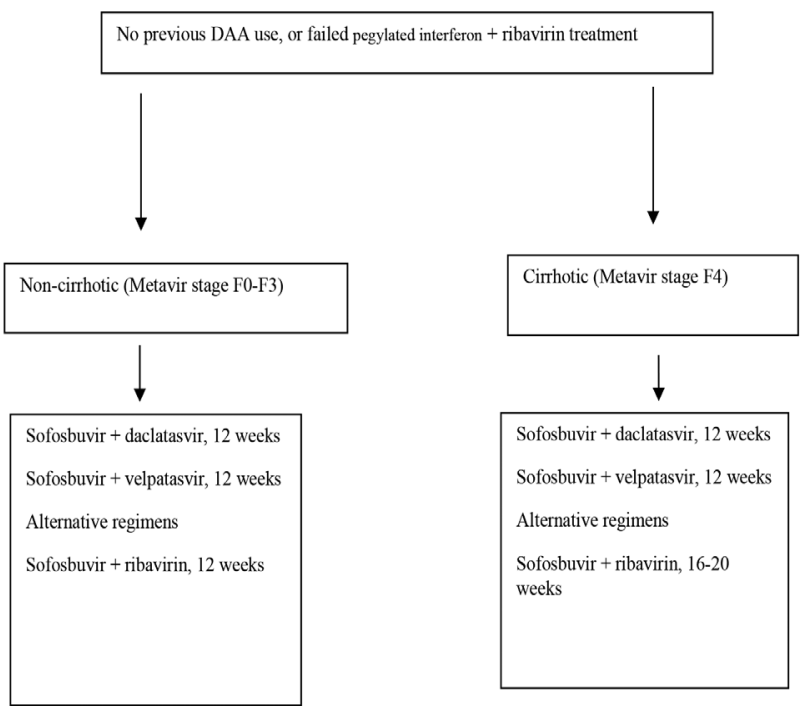

Algorithm 3. Selection of antiviral treatment for patients with hepatitis $C$ virus genotype 2 infection ${ }^{[73,84]}$

The addition of $\mathrm{R}$ to the regimens is not necessary according to Turkish guidelines ${ }^{[73]}$. In preliminary studies on the use of sofosbuvir/velpatasvir, treatment failure was not observed in any patients with genotype 2 infection ${ }^{[56]}$.

Treatment After Direct-acting Antiviral Agents Failure

Failed Treatment with Sofosbuvir + R (NS5A-naive)

Sofosbuvir/velpatasvir is recommended for 12 weeks. Sustained virologic response rate with this treatment is reported to be $97 \%{ }^{[84]}$. Although available data are very limited, using sofosbuvir + daclatasvir $\pm R$ for 24 weeks is another option.

Sofosbuvir + NS5A-experienced Cases

Since treatment with sofosbuvir/velpatasvir rarely fails in genotype 2 patients, sofosbuvir/velpatasvir $+\mathrm{R}$ is recommended for 24 weeks $^{[85]}$.

Treatment-naive Patients or peg-IFN + R Experienced Patients Infected with Genotype 3 (Algorithm 4) ${ }^{[84]}$

The DAA regimen options for this group are sofosbuvir + daclatasvir, and sofosbuvir/velpatasvir. Regimen implementation varies depending on the presence of cirrhosis. For optimal efficacy, treatment-naive patients without cirrhosis should take sofosbuvir + R for 24 weeks. Although SVR rates of $90-95 \%$ have been observed, lower rates are reported in real world data ${ }^{[86,87]}$. Sofosbuvir/ledipasvir + R may be effective when used for 12 weeks with this group of patients, but is not recommended due to concerns about the in vitro efficacy of ledipasvir against genotype 3 and the availability of better regimens ${ }^{[8]}$. 


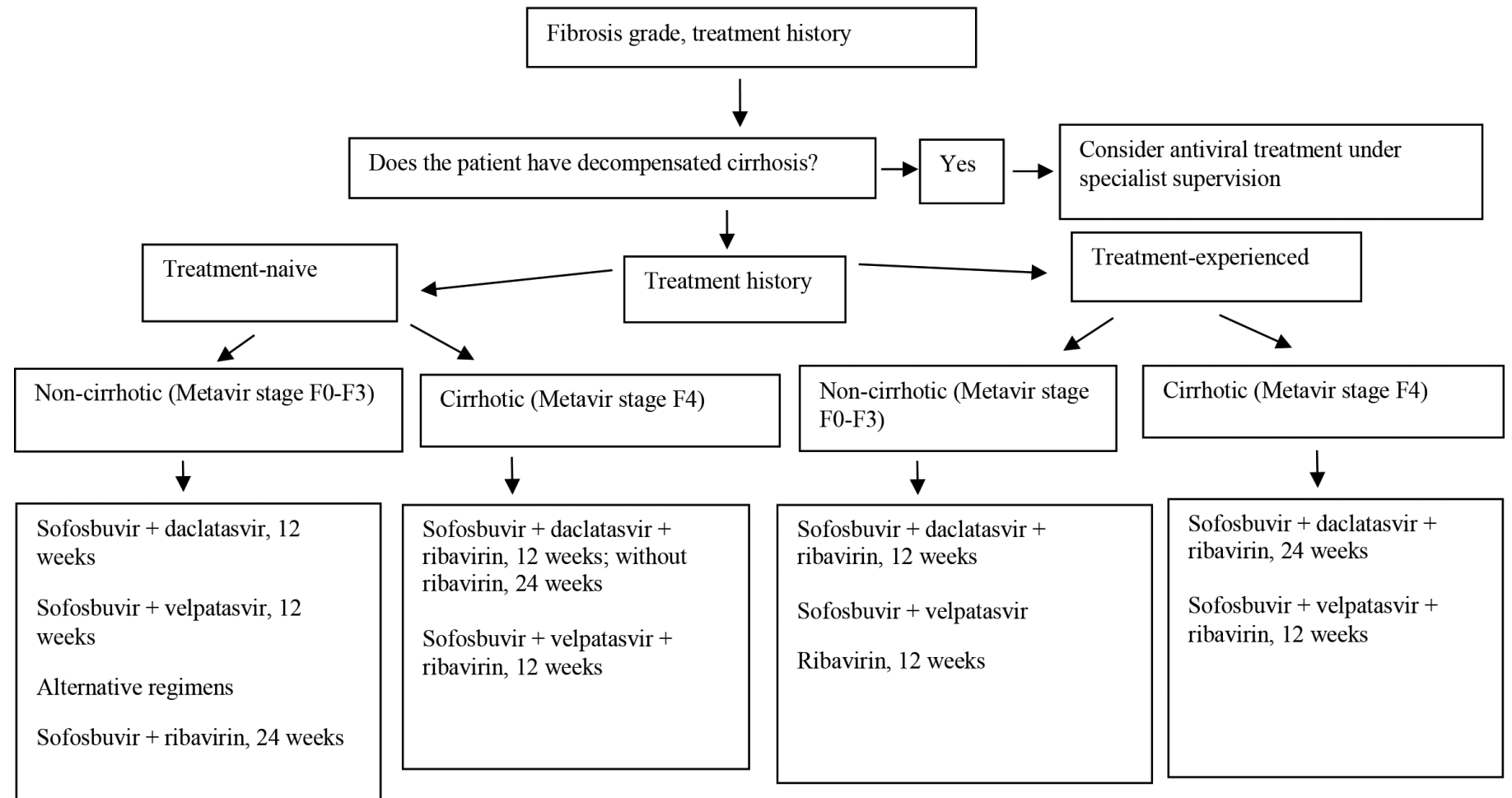

Algorithm 4. Selection of antiviral treatment for patients with hepatitis $C$ virus genotype 3 infection ${ }^{[73,84]}$

Table 5. Antiviral therapy in treatment-naive cases with HCV genotype 4, 5, and 6 infection ${ }^{[73]}$

\begin{tabular}{l|l}
\multicolumn{2}{l}{ Genotype 4, treatment-naive patients without cirrhosis } \\
\hline Recommended treatment & Duration \\
\hline Ombitasvir-paritaprevir/ritonavir + ribavirin & 12 weeks \\
\hline Sofosbuvir + velpatasvir & 12 weeks \\
\hline Elbasvir + grazoprevir & 12 weeks \\
\hline Sofosbuvir + ledipasvir & 12 weeks \\
\hline
\end{tabular}

Genotype 4, treatment-naive patients with compensated cirrhosis

\begin{tabular}{l|l}
\hline Ombitasvir-paritaprevir/ritonavir + ribavirin & 12 weeks \\
\hline Sofosbuvir + velpatasvir & 12 weeks \\
\hline Elbasvir + grazoprevir & 12 weeks \\
\hline Sofosbuvir + ledipasvir & 12 weeks \\
\hline
\end{tabular}

Genotype 5 and 6, treatment-naive patients with cirrhosis and compensated cirrhosis

\begin{tabular}{l|l}
\hline Sofosbuvir + velpatasvir & 12 weeks \\
\hline Sofosbuvir + ledipasvir & 12 weeks
\end{tabular}

Table 6. Antiviral therapy in treatment-experienced cases with HCV genotype 4, 5, and 6 infection ${ }^{[73]}$

Genotype 4, pegIFN/Ribavirin treatment-experienced patients without cirrhosis

\begin{tabular}{l|l}
\hline Ombitasvir-paritaprevir/ritonavir + ribavirin & 12 weeks \\
\hline Sofosbuvir + velpatasvir & 12 weeks \\
\hline Elbasvir + grazoprevir (patients with relapse) & 12 weeks \\
\hline $\begin{array}{l}\text { Elbasvir + grazoprevir + ribavirin (patients with } \\
\text { treatment failure or breakthrough) }\end{array}$ & 16 weeks \\
\hline Sofosbuvir + ledipasvir & 12 weeks \\
\hline
\end{tabular}

Genotype 4, pegIFN/Ribavirin treatment-experienced patients with compensated cirrhosis

\begin{tabular}{l|l}
\hline Ombitasvir-paritaprevir/ritonavir + ribavirin & 12 weeks \\
\hline Sofosbuvir + velpatasvir & 12 weeks \\
\hline Elbasvir + grazoprevir (patients with relapse) & 12 weeks \\
\hline $\begin{array}{l}\text { Elbasvir + grazoprevir + ribavirin (patients with } \\
\text { treatment failure or breakthrough) }\end{array}$ & 16 weeks \\
\hline Sofosbuvir + ledipasvir + ribavirin & 12 weeks \\
\hline
\end{tabular}

Genotype 5 and 6, pegIFN/ribavirin treatment-experienced patients with cirrhosis and compensated cirrhosis

\begin{tabular}{l|l}
\hline Sofosbuvir + velpatasvir & 12 weeks \\
\hline Sofosbuvir + ledipasvir & 12 weeks
\end{tabular}




\section{Treatment Selection for Patients Infected with Genotype 4, 5 , and 6}

Treatment options and durations for treatment-naive and treatment-experienced cases infected with these genotypes are given in Tables 5 and $6^{[73]}$.

\section{Conclusion}

There have been remarkable developments in recent years concerning the use of antivirals in the treatment of chronic $\mathrm{HCV}$ infection. These treatment options are attractive due to the low side effects and toxicities as well as ease of treatment compliance and high SVR rates even in problematic patient groups (those with cirrhosis, renal failure, etc.), and offer hope for overcoming the problem of HCV infection in the future.

\section{Ethics}

Peer-review: Externally and internally peer-reviewed.

Financial Disclosure: The author declared that this study received no financial support.

\section{References}

1. Mohd Hanafiah K, Groeger, J, Flaxman AD, Wiersma ST. Global epidemiology of hepatitis $C$ virus infection: New estimates of age-specific antibody to HCV seroprevalence. Hepatology. 2013;57:1333-42.

2. Messina JP, Humphreys I, Flaxman A, Brown A, Cooke GS, Pybus OG, Barnes E. Global distribution and prevalence of hepatitis $C$ virus genotypes. Hepatology. 2015;61:77-87

3. Simmons B, Saleem J, Hill A, Riley RD, Cooke GS. Risk of late relapse or reinfection with hepatitis $C$ virus after achieving a sustained virological response: A systematic review and meta-analysis. Clin Infect Dis. 2016;62:683-94.

4. Gower E, Estes C, Blach S, Razavi-Shearer K, Razavi H. Global epidemiology and genotype distribution of the hepatitis $\mathrm{C}$ virus infection. J Hepatol. 2014;61(Suppl 1):S45-57.

5. Tözün N, Özdoğan O, Çakaloğlu Y İdilman R, Karasu Z, Akarca U, Kaymakoglu $S$, Ergonul 0. Seroprevalance of hepatitis $B$ and $C$ virus infections and risk factors in Turkey: a fieldwork TURHEP study. Clin Microbiol Infect. 2015;21:1020-6.

6. Gürbüz Y, Tülek N, Tütüncü EE. Evaluation of dual therapy in real life setting in treatment naive Turkish patients with HCV infection: A multicenter retrospective study. Balkan Med J. 2016;33:18-26.

7. Altuğlu I, Sertöz R, Aksoy A, Gürsel D, Tüzüner U, Günşar F. Possible transmission risks and genotype distribution of hepatitis $C$ virus infection in Western Turkey. Turk J Gastroenterol. 2013;24:349-55.

8. Sen GC. Viruses and interferons. Annu Rev Microbiol. 2001;55:255-81.

9. Gutierrez JA, Lawitz EJ, Poordad F. Interferon-free, direct-acting antiviral therapy for chronic hepatitis C. J Viral Hepat. 2015;22:861-70.

10. Bartenschlager R, Lohmann V, Penin F. The molecular and structural basis of advanced antiviral therapy for hepatitis $\mathrm{C}$ virus infection. Nat Rev Microbiol. 2013;11:482-96.

11. Asma A, Felmlee DJ. Mechanisms of hepatitis C viral resistance to direct acting antivirals. Viruses. 2015;7:6716-29.

12. Moradpour D, Penin F, Rice CM. Replication of hepatitis C virus. Nat Rev Microbiol. 2007:5:453-63.
13. Lemon SM, McKeating JA, Pietschmann T, Frick DN, Glenn JS, Tellinghuisen TL, Symons J, Furman PA. Development of novel therapies for hepatitis C. Antiviral Res. 2010;86:79-92.

14. Ünsal B. Kronik HCV enfeksiyonunda antiviral tedavinin amaçları. Kandemir Ö, Danalığlu A (editörler) Hepatit B'den D'ye Hep Güncel Kitabı, (editörler). 2015 Birinci baskı;156-65.

15. Schaefer EA, Chung RT. Anti-hepatitis C virus drugs in development. Gastroenterology. 2012;142:1340-50.e1.

16. Hunt $D$, Pockros P. What are the promising new therapies in the field of chronic hepatitis $\mathrm{C}$ after the first-generation direct-acting antivirals? Curr Gastroenterol Rep. 2013;15:303-13.

17. Pockros PJ. Direct acting antivirals for the treatment of hepatitis $C$ virüs infection. Di Bisceglie AM (Ed). UpToDate. Available from: www.uptodate. com. Last accessed date: 10.07.2015.

18. Tencate V, Sainz B Jr, Cotler SJ, Uprichard SL. Potential treatment options and future research to increase hepatitis $C$ virus treatment response rate. Hepat Med. 2010;2:125-45.

19. Poordad F, Dieterich D. Treating hepatitis C: current standard of care and emerging direct-acting antiviral agents. J Viral Hepatitis. 2012;19:449-64.

20. Lenz O, Fevery B, Verbinnen T, Tambuyzer L, Vijgen L, Peeters M, BeumontMauviel M, Picchio G, Meyer SD. Resistance analyses of HCV isolates from patients treated with simeprevir in Phase IIB/III studies (Abstract 1101). AASLD. 2013.

21. Olysio (simeprevir). US FDA approved product information. National Library of Medicine. Last accessed date: 17.08. 2017. Available from: http:// dailymed.nIm.nih.gov/dailymed/lookup.cfm?setid=1816fd68-0ed7-4a37$84 \mathrm{bb}-\mathrm{e} 298 \mathrm{c} 5 \mathrm{ab} 6 \mathrm{e} 28$.

22. Fontaine $H$, Lazarus $A, P o l ~ S$, Pecriaux $C$, Bagate $F$, Sultanik $P$, Boueyre $E$ Corouge M, Mallet V, Vallet-Pichard A, Sogni P, Duboc D; Cochin Hepatology and Cardiology Group. Bradyarrhythmias Associated with Sofosbuvir Treatment. N Engl J Med. 2015;373:1886-8.

23. Renet S, Chaumais MC, Antonini T, Zhao A, Thomas L, Savoure A, Samue D, Duclos-Vallée JC, Algalarrondo V. Extreme bradycardia after first doses of sofosbuvir and daclatasvir in patients receiving amiodarone: 2 cases including a rechallenge. Gastroenterology. 2015;149:1378-80.

24. Rajyaguru $S, X u S$, Hebner $C$, Hebner $C$, Svarovskaia ES, Gontcharova $V_{i}$ Doehle B, Miller MD, Sciences HMG, City F. Sofosbuvir selects the NS5B S282T mutation in vitro in genotype 1-6 replicons and is not cross-resistant to resistance associated variants selected by other classes of antiviral inhibitors. AASLD. 2013;1-5

25. Tellinghuisen $\mathrm{TL}$, Foss $\mathrm{KL}$, Treadaway J. Regulation of hepatitis $\mathrm{C}$ virion production via phosphorylation of the NS5A protein. PLoS Pathog. 2008:4:e1000032.

26. Sulkowski MS, Gardiner DF, Rodriguez-Torres $M$, Hassanein $T$, Jacobson I, Lawitz E, Lok AS, Hinestrosa F, Thuluvath PJ, Schwartz H, Nelson DR, Everson GT, Eley $T$, Wind-Rotolo $M$, Huang SP, Gao M, Hernandez D, McPhee $F$, Sherman D, Hindes R, Symonds W, Pasquinelli C, Grasela DM; Al444040 Study Group. Daclatasvir plus sofosbuvir for previously treated or untreated chronic HCV infection. N Engl J Med. 2014;370:211-21.

27. Nelson DR, Cooper JN, Lalezari JP, Lawitz E, Pockros PJ, Gitlin N, Freilich BF, Younes ZH, Harlan W, Ghalib R, Oguchi G, Thuluvath PJ, Ortiz-Lasanta G, Rabinovitz M, Bernstein D, Bennett M, Hawkins T, Ravendhran N, Sheikh AM, Varunok P, Kowdley KV, Hennicken D, McPhee F, Rana K, Hughes EA ALLY-3 Study Team. All-oral 12-week treatment with daclatasvir plus sofosbuvir in patients with hepatitis C virus genotype 3 infection: ALLY-3 phase III study. Hepatology. 2015;61:1127-35.

28. Zeuzem S, Ghalib R, Reddy KR, Pockros PJ, Ben Ari Z, Zhao Y, Brown DD, Wan S, DiNubile MJ, Nguyen BY, Robertson MN, Wahl J, Barr E, Butterton JR. Grazoprevir-Elbasvir combination therapy for treatment-naive cirrhotic and noncirrhotic patients with chronic hepatitis $C$ virus genotype 1,4 , or 6 infection: A randomized trial. Ann Intern Med. 2015;163:1-13. 
29. Lawitz E, Gane E, Pearlman B, Tam E, Ghesquiere W, Guyader D, Alric L, Bronowicki JP, Lester L, Sievert W, Ghalib R, Balart L, Sund F, Lagging $M$, Dutko F, Shaughnessy M, Hwang P, Howe AY, Wahl J, Robertson M, Barr E, Haber B. Efficacy and safety of 12 weeks versus 18 weeks of treatment with grazoprevir (MK-5172) and elbasvir (MK-8742) with or without ribavirin for hepatitis $C$ virus genotype 1 infection in previously untreated patients with cirrhosis and patients with previous null response with or without cirrhosis (C-WORTHY): a randomised, open-label phase 2 trial. Lancet. 2015;385:1075-86.

30. Pawlotsky JM. Hepatitis $C$ virus resistance to direct-acting antiviral drugs in interferon-free regimens. Gastroenterology. 2016;151:70-86.

31. Au JS, Pockros PJ. Novel therapeutic approaches for hepatitis C. Clin Pharmacol Ther. 2014;95:78-88.

32. Wyles D, Dvory-Sobol H, Svarovskaia ES, Doehle BP, Martin R, Afdhal $\mathrm{NH}$, Kowdley KV, Lawitz E, Brainard DM, Miller MD, Mo H, Gane EJ. Posttreatment resistance analysis of hepatitis $\mathrm{C}$ virus from phase II and III clinical trials of ledipasvir/sofosbuvir. J Hepatol. 2017;66:703-10.

33. Feld JJ, Kowdley KV, Coakley E, Sigal S, Nelson DR, Crawford D, Weiland O, Aguilar H, Xiong J, Pilot-Matias T, DaSilva-Tillmann B, Larsen L, Podsadecki T, Bernstein B. Treatment of HCV with ABT-450/r-ombitasvir and dasabuvir with ribavirin. N Engl J Med. 2014;370:1594-603.

34. Zeuzem $S$, Jacobson IM, Baykal $T$, Marinho RT, Poordad $F$, Bourlière $M$, Sulkowski MS, Wedemeyer H, Tam E, Desmond P, Jensen DM, Di Bisceglie AM, Varunok P, Hassanein T, Xiong J, Pilot-Matias T, DaSilva-Tillmann B, Larsen L, Podsadecki T, Bernstein B. Retreatment of HCV with ABT-450/rombitasvir and dasabuvir with ribavirin. N Engl J Med. 2014;370:1604-14.

35. Ferenci P, Bernstein D, Lalezari J, Cohen D, Luo Y, Cooper C, Tam E, Marinho RT, Tsai N, Nyberg A, Box TD, Younes Z, Enayati P, Green S, Baruch Y, Bhandari BR, Caruntu FA, Sepe T, Chulanov V, Janczewska E, Rizzardini G, Gervain J, Planas R, Moreno C, Hassanein T, Xie W, King M, Podsadecki T, Reddy KR; PEARL-III Study; PEARL-IV Study. ABT-450/r-ombitasvir and dasabuvir with or without ribavirin for HCV. N Engl J Med. 2014;370:1983-92.

36. Feld JJ, Jacobson IM, Hézode C, Asselah T, Ruane PJ, Gruener N, Abergel A, Mangia A, Lai CL, Chan HL, Mazzotta F, Moreno C, Yoshida E, Shafran SD, Towner WJ, Tran TT, McNally J, Osinusi A, Svarovskaia E, Zhu Y, Brainard DM, McHutchison JG, Agarwal K, Zeuzem S; ASTRAL-1 Investigators. Sofosbuvir and Velpatasvir for HCV Genotype 1, 2, 4, 5, and 6 Infection. N Engl J Med. 2015;373:2599-607.

37. Zeuzem S, Feld J, Wang S, Bourliere M, Wedemeyer H, Gane E, Flisiak R, Chuang WL, Flamm S, Kwo P, Sepulveda-Arzola G, Soto-Malave R, Puoti M, Tam E, Bruck R, Fuster F, Paik SW, Felizarta F, Fu B, Ng TI, Lin CW, Mensa F. ENDURANCE-1: A Phase 3 Evaluation of the Efficacy and Safety of 8- versus 12-week Treatment with Glecaprevir/Pibrentasvir (formerly ABT493/ABT-530) in HCV Genotype 1 Infected Patients with or without HIV-1 Co-infection and without Cirrhosis. Presented at the American Association for the Study of Liver Diseases Liver Meeting, Boston, MA, November 11-15, 2016.

38. Puoti M, Foster G, Wang S, Mutimer D, Gane E, Moreno C, Chang TT, Lee SS, Marinho R, Dufour JF, Pol S, Hezode C, Gordon SC, Strasser SI, Thuluvath PJ, Liu R, Pilot-Matias T, Mensa F. High SVR Rates With Eight and Twelve Weeks of Pangenotypic Glecaprevir/Pibrentasvir: Integrated Efficacy Analysis of Genotype 1-6 Patients Without Cirrhosis. Presented at the $52^{\text {nd }}$ Annual Meeting of the European Association for the Study of the Liver (EASL), Amsterdam, The Netherlands, April 19-23, 2017.

39. Forns $X$, Lee $S S$, Valdes J, Lens $S$, Ghalib R, Aguilar $H$, Felizarta $F$, Hassanein $T$, Hinrichsen $H$, Rincon D, Morillas R, Zeuzem S, Horsmans $Y$, Nelson DR, Yu Y, Krishnan P, Lin CW, Kort JJ, Mensa FJ. Glecaprevir plus pibrentasvir for chronic hepatitis $C$ virus genotype $1,2,4,5$, or 6 infection in adults with compensated cirrhosis (EXPEDITION-1): a single-arm, open-label, multicentre phase 3 trial. Lancet Infect Dis. 2017;17:1062-3.

40. Poordad F, Pol S, Asatryan A. MAGELLAN-1, Part 2: Glecaprevir/pibrentasvir for 12 or 16 weeks in patients with chronic HCV genotype 1 or 4 and prior direct-acting antiviral treatment failure. Presented at the 52nd Annual
Meeting of the European Association for the Study of the Liver (EASL), Amsterdam, The Netherlands, April 19-23, 2017.

41. Bourlière $M$, Bronowicki JP, de Ledinghen $V$, Hézode $C$, Zoulim $F$, Mathurin $P$, Tran A, Larrey DG, Ratziu V, Alric L, Hyland RH, Jiang D, Doehle B, Pang PS, Symonds WT, Subramanian GM, McHutchison JG, Marcellin P, Habersetzer F, Guyader D, Grangé JD, Loustaud-Ratti V, Serfaty L, Metivier S, Leroy V, Abergel A, Pol S. Ledipasvir-sofosbuvir with or without ribavirin to treat patients with HCV genotype 1 infection and cirrhosis non-responsive to previous protease-inhibitor therapy: a randomised, double-blind, phase 2 trial (SIRIUS). Lancet Infect Dis. 2015;15:397-404.

42. Dufour JF, Zuckerman E, Zadeikis N. Safety of Glecaprevir/Pibrentasvir in Adults With Chronic Genotype 1-6 Hepatitis C Virus Infection: An Integrated Analysis. Presented at the 52nd Annual Meeting of the European Association for the Study of the Liver (EASL), Amsterdam, The Netherlands, April 19-23, 2017.

43. Ng T, Lu L, Reisch T, Krishnan P, Schnell G, Tripathi R, Beyer J, Dekhtyar T, Irvin $\mathrm{M}$, Pilot-Matias $\mathrm{T}$, Collins $\mathrm{C}$. Resistance selection using glecaprevir and pibrentasvir in replicons of major hepatitis $C$ virus genotypes. J Hepatol. 2017;66:S324-26.

44. Bourlière M, Gordon SC, Flamm SL, Cooper CL, Ramji A, Tong M, Ravendhran $\mathrm{N}$, Vierling JM, Tran $\Pi$, Pianko $S$, Bansal MB, de Lédinghen $V$, Hyland $R H$, Stamm LM, Dvory-Sobol H, Svarovskaia E, Zhang J, Huang KC, Subramanian GM, Brainard DM, McHutchison JG, Verna EC, Buggisch P, Landis CS, Younes ZH, Curry MP, Strasser SI, Schiff ER, Reddy KR, Manns MP, Kowdley KV, Zeuzem S; POLARIS-1 and POLARIS-4 Investigators. Sofosbuvir, Velpatasvir, and Voxilaprevir for Previously Treated HCV Infection. N Engl J Med. 2017;376:2134-46.

45. Lawitz E, Poordad F, Wells J, Hyland RH, Yang Y, Dvory-Sobol H, Stamm LM, Brainard DM, McHutchison JG, Landaverde C, Gutierrez J. Sofosbuvirvelpatasvir-voxilaprevir with or without ribavirin in direct-acting antiviralexperienced patients with genotype 1 hepatitis C virus. Hepatology. 2017;65:1803-9.

46. Jacobson IM, McHutchison JG, Dusheiko G, Di Bisceglie AM, Reddy KR, Bzowej NH, Marcellin P, Muir AJ, Ferenci P, Flisiak R, George J, Rizzetto M, Shouval D, Sola R, Terg RA, Yoshida EM, Adda N, Bengtsson L, Sankoh AJ, Kieffer TL, George S, Kauffman RS, Zeuzem S; ADVANCE Study Team. Telaprevir for previously untreated chronic hepatitis $C$ virus infection. N Engl J Med. 2011;364:2405-16.

47. Poordad F, McCone Jr J, Bacon BR, Bruno S, Manns MP, Sulkowski MS, Jacobson IM, Reddy KR, Goodman ZD, Boparai N, DiNubile MJ, Sniukiene V, Brass CA, Albrecht JK, Bronowicki JP; SPRINT-2 Investigators. Boceprevir for untreated chronic HCV genotype 1 infection. N Engl J Med. 2011;364:1195206.

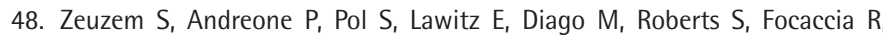
Younossi Z, Foster GR, Horban A, Ferenci P, Nevens F, Müllhaupt B, Pockros $P$, Terg R, Shouval D, van Hoek B, Weiland O, Van Heeswijk R, De Meyer S, Luo D, Boogaerts G, Polo R, Picchio G, Beumont M; REALIZE Study Team. Telaprevir for retreatment of HCV infection. N Engl J Med. 2011;364:2417-28.

49. Garcia-Retortillo M, Forns X, Feliu A, Moitinho E, Costa J, Navasa M, Rimola $A$, Rodes J. Hepatitis $C$ virus kinetics during and immediately after liver transplantation. Hepatology. 2002;35:680-7.

50. Gane E, Pilmore H. Management of chronic viral hepatitis before and after renal transplantation. Transplantation. 2002;74:427-37.

51. Poordad F, Hezode C, Trinh R, Kowdley KV, Zeuzem S, Agarwal K, Shiffman ML, Wedemeyer H, Berg T, Yoshida EM, Forns X, Lovell SS, Da Silva-Tillmann B, Collins CA, Campbell AL, Podsadecki T, Bernstein B. ABT-450/ r-ombitasvir and dasabuvir with ribavirin for hepatitis $C$ with cirrhosis. N Engl J Med. 2014;370:1973-82.

52. Forman LM, Lewis JD, Berlin JA, Feldman HI, Lucey MR. The association between hepatitis $\mathrm{C}$ infection and survival after orthotopic liver transplantation. Gastroenterology. 2002;122:889-96. 
53. Prieto $M$, Berenguer $M$, Rayon JM, Cordoba J, Arguello L, Carrasco $D$, García-Herola A, Olaso V, De Juan M, Gobernado M, Mir J, Berenguer J. High incidence of allograft cirrhosis in hepatitis $C$ virus genotype $1 \mathrm{~b}$ infection following transplantation: relationship with rejection episodes. Hepatology. 1999;29:250-6.

54. Blasco A, Forns X, Carrion JA, Garcia-Pagan JC, Gilabert R, Rimola A, et al. Hepatic venous pressure gradient identifies patients at risk of severe hepatitis C recurrence after liver transplantation. Hepatology. 2006;43:4929.

55. Neumann UP, Berg T, Bahra M, Seehofer D, Langrehr JM, Neuhaus R, Radke C, Neuhaus P. Fibrosis progression after liver transplantation in patients with recurrent hepatitis C. J Hepatol. 2004;41:830-6.

56. Lawitz $E_{1}$ Sulkowski MS, Ghalib R, Rodriguez-Torres M, Younossi ZM, Corregidor A, DeJesus E, Pearlman B, Rabinovitz M, Gitlin N, Lim JK, Pockros PJ, Scott JD, Fevery B, Lambrecht T, Ouwerkerk-Mahadevan S, Callewaert K, Symonds WT, Picchio G, Lindsay KL, Beumont M, Jacobson IM. Simeprevir plus sofosbuvir, with or without ribavirin, to treat chronic infection with hepatitis $C$ virus genotype 1 in non-responders to pegylated interferon and ribavirin and treatment-naive patients: the COSMOS randomised study. Lancet. 2014;384:1756-65.

57. Jensen DM, O'Leary JG, Pockros PJ, Sherman KE, Kwo PY, Mailliard ME, Kowdley K, Muir A, Dickson R, Ramani A, Manns M, Lok A, Akushevich L, Nelson D, Fried M. Safety and efficacy of sofosbuvir-containing regimens for hepatitis $\mathrm{C}$ : realworld experience in a diverse, longitudinal observational cohort. Hepatology. 2014;60:219A.

58. Hadziyannis SJ, Sette H Jr, Morgan TR, Balan V, Diago M, Marcellin P, Ramadori G, Bodenheimer H Jr, Bernstein D, Rizzetto M, Zeuzem S, Pockros PJ, Lin A, Ackrill AM; PEGASYS International Study Group. Peginterferonalpha2a and ribavirin combination therapy in chronic hepatitis C: a randomized study of treatment duration and ribavirin dose. Ann Intern Med. 2004;140:346-55.

59. Dieterich D, Bacon BR, Flamm SL, Kowdley KV, Milligan S, Tsai N, et al. Evaluation of sofosbuvir and simeprevir-based regimens in the TRIO network: academic and community treatment of a real-world, heterogeneous population. Hepatology. 2014;60:220A.

60. Leroy V, Dumortier J, Coilly A, Sebagh M, Fougerou-Leurent C, Radenne S, et al. High rates of virological response and major clinical improvement during sofosbuvir and daclatasvir-based regimens for the treatment of fibrosing cholestatic HCV recurrence after liver transplantation: the ANRS CO23 CUPILT study. Hepatology. 2014;60:207A.

61. Thomas DL, Astemborski J, Rai RM, Anania FA, Schaeffer M, Galai N, Nolt K, Nelson KE, Strathdee SA, Johnson L, Laeyendecker O, Boitnott J, Wilson LE, Vlahov D. The natural history of hepatitis $C$ virus infection: host, viral, and environmental factors. JAMA. 2000;284:450-6.

62. Sulkowski MS, Hézode C, Gerstoft J, Vierling JM, Mallolas J, Pol S, Kugelmas M, Murillo A, Weis N, Nahass R, Shibolet O, Serfaty L, Bourliere M, DeJesus E, Zuckerman E, Dutko $F$, Shaughnessy $M$, Hwang $P$, Howe AY, Wahl J, Robertson $\mathrm{M}$, Barr E, Haber B. Efficacy and safety of 8 wks versus 12 wks of treatment with grazoprevir (MK-5172) and elbasvir (MK-8742) with or without ribavirin in patients with HCV GT1 monoinfection and HIV/HCV coinfection (C-WORTHY): a randomised, open-label phase 2 trial. Lancet. 2015;285:1087-97.

63. Kwo PY, Gane EJ, Peng CY, Pearlman B, Vierling JM, Serfaty L, Buti M, Shafran S, Stryszak P, Lin L, Gress J, Black S, Dutko FJ, Robertson M, Wahl J, Lupinacci L, Barr E, Haber B. Effectiveness of Elbasvir and Grazoprevir Combination, With or Without Ribavirin, for Treatment-Experienced Patients With Chronic Hepatitis C Infection. Gastroenterology. 2017;152:164-75.e4

64. Kowdley KV, Colombo $M$, Zadeikis $N$, Mantry PS, Calinas $F$, Aguilar $H$, Ledinghen WD, Horsmans $Y, \mathrm{Hu} Y, \mathrm{Ng}$ Tl, Mensa F. ENDURANCE-2: Safety and Efficacy of ABT-493/ABT-530 in Hepatitis C Virus Genotype 2-Infected Patients. Without Cirrhosis: A Randomized, Double-Blind, PlaceboControlled Study. (Abstract 73). AASLD. 2016.
65. Foster GR, Gane E, Asatryan A, Asselah T, Ruane PJ, Pol S, Poordad F, Stedman CA, Dore G, Roberts SK, Kaita K, Vierling J, Vargas HE, Kort J, Lin CW, Liu R, Ng T, Mensa F. ENDURANCE-3: safety and efficacy of glecaprevir/pibrentasvir compared to sofosbuvir plus daclatasvir in treatment-naïve HCV genotype 3-infected patients without cirrhosis. J Hepatology. 2017;66:S33.

66. Asselah T, Hezode C, Zadeikis N, Elkhashab M, Colombo M, Marinho RT, Agarwal K, Nevens F, Liu R, Teresa M, Federico M. ENDURANCE-4: Efficacy and Safety of ABT-493/ABT-530 Treatment in Patients with Chronic HCV Genotype 4, 5, or 6 Infection (Abstract 114). AASLD. 2016.

67. Kwo PY, Poordad F, Asatryan A, Wang S, Wyles DL, Hassanein T, Felizarta F, Sulkowski MS, Gane E, Maliakkal B, Overcash JS, Gordon SC, Muir AJ, Aguilar H, Agarwal K, Dore GJ, Lin CW, Liu R, Lovell SS, Ng TI, Kort J, Mensa FJ. Glecaprevir and pibrentasvir yield high response rates in patients with HCV genotype 1-6 without cirrhosis. J Hepatology. 2017;67:263-71.

68. Hassanein T, Wyles D, Wang S, Kwo P, Shiffman ML, Younes Z, Greenbloom $\mathrm{S}$, Stedman, Sasadeusz J, Aguilar H, Heo J, Liu R, Ng T, Lin CV, Mensa F. SURVEYOR-II, Part 4: Glecaprevir/Pibrentasvir Demonstrates High SVR Rates in Patients With HCV Genotype 2, 4, 5, or 6 Infection Without Cirrhosis Following an 8-Week Treatment Duration (Abstract LB-15). AASLD. 2016.

69. Rockstroh JK, Lacombe K, Viani RM, Orkin C, Wyles D, Luetkemeyer AF, Soto-Malave $R$, Flisiak R, Bhagani $S$, Sherman KE, Shimonova $T$, Ruane $P$, Sasadeusz J, Slim J, Zhang Z, Ng TI, Trinh R, Sulkowski M. Efficacy and safety of Glecaprevir/Pibrentasvir in patients co-infected with hepatitis $C$ virus and human immunodeficiency virus-1: the EXPEDITION-2 Study (LBP-522). Journal of Hepatology. 2017;66(Supplement):102-3.

70. Foster GR, Pianko $S$, Brown A, Forton D, Nahass RG, George J, Barnes $E$, Brainard DM, Massetto B, Lin M, Han B, McHutchison JG, Subramanian GM, Cooper C, Agarwal K; BOSON Study Group. Efficacy of sofosbuvir plus ribavirin with or without peginterferon-alfa in patients with hepatitis $C$ virus genotype 3 infection and treatment-experienced patients with cirrhosis and hepatitis C virus genotype 2 infection. Gastroenterology. 2015;149:1462-70.

71. Foster GR, Afdhal NH, Roberts SK. Sofosbuvir and Velpatasvir for HCV Genotype 2 and 3 Infection. N Engl J Med. 2015;373:2608-17.

72. Jacobson IM, Lawitz E, Gane EJ, Willems BE, Ruane PJ, Nahass RG, Borgia SM, Shafran SD, Workowski KA, Pearlman B, Hyland RH, Stamm LM, Svarovskaia E, Dvory-Sobol H, Zhu Y, Subramanian GM, Brainard DM, McHutchison JG, Bräu N, Berg T, Agarwal K, Bhandari BR, Davis M, Feld JJ, Dore GJ, Stedman CAM, Thompson AJ, Asselah T, Roberts SK, Foster GR. Efficacy of 8 Weeks of Sofosbuvir, Velpatasvir, and Voxilaprevir in Patients With Chronic HCV Infection: 2 Phase 3 Randomized Trials. Gastroenterology. 2017;153:113-22.

73. Türkiye Viral Hepatitler Tanı ve Tedavi Kılavuzu 2017. Last accessed date: 18.11.2017. Available from: http://www.vhsd.org/tr/page/turkiye-viralhepatitliler-tani-ve-tedavi-kilavuzu-2-7.html

74. Sidharthan S, Kohli A, Sims Z, Nelson A, Osinusi A, Masur H, Kottilil S. Utility of hepatitis $C$ viral load monitoring on direct-acting antiviral therapy. Clin Infect Dis. 2015;60:1743-51.

75. Recommendations for Testing, Managing, and Treating Hepatitis C. Joint panel from the American Association of the Study of Liver Diseases and the Infectious Diseases Society of America. Last accessed date: 23.01.2018. Available from: http://www.hcvguidelines.org/

76. Poordad F, Agarwal K, Younes Z, Cohen D, Xie W and Podsadeckiet T. Low relapse rate leads to high concordance of sustained virologic response (SVR) at 12 weeks with SVR at 24 weeks after treatment with ABT-450/ ritonavir, ombitasvir, and dasabuvir plus ribavirin in subjects with chronic hepatitis $C$ virus genotype 1 infection in the AVIATOR study. Clin Infect Dis. 2015;60:608-11.

77. Sarrazin C, Isakov V, Svarovskaia ES, Hedskog C, Martin R, Chodavarapu K, Brainard DM, Miller MD, Mo H, Molina JM, Sulkowski MS. Late relapse versus hepatitis $C$ virus reinfection in patients with sustained virologic response after sofosbuvir-based therapies. Clin Infect Dis. 2017;64:44-52. 
78. Chopra S, Muir AJ. Treatment regimens for chronic hepatitis $C$ virus genotype 1 infection in adults. Di Biscegile AM (ed). Erişim tarihi: 11.09.2017. Erişim adresi: www.uptodate.com.

79. Lawitz E, Poordad FF, Pang PS, Hyland RH, Ding $X$, Mo H, Symonds WT, McHutchison JG, Membreno FE. Sofosbuvir and ledipasvir fixed-dose combination with and without ribavirin in treatment-naive and previously treated patients with genotype 1 hepatitis $C$ virus infection (LONESTAR): an open-label, randomised, phase 2 trial. Lancet. 2014;383:515-23.

80. Afdhal N, Zeuzem S, Kwo P, Chojkier M, Gitlin N, Puoti M, Romero-Gomez M, Zarski JP, Agarwal K, Buggisch P, Foster GR, Bräu N, Buti M, Jacobson IM, Subramanian GM, Ding $X$, Mo $H$, Yang JC, Pang PS, Symonds WT, McHutchison JG, Muir AJ, Mangia A, Marcellin P; ION-1 Investigators. Ledipasvir and sofosbuvir for untreated HCV genotype 1 infection. N Engl J Med. 2014;370:1889-98.

81. European Association for the Study of the Liver. Electronic address: easloffice@easloffice.eu. EASL Recommendations on Treatment of Hepatitis C 2016. J Hepatol 2017;66:153.

82. Afdhal N, Reddy KR, Nelson DR, Lawitz E, Gordon SC, Schiff E, Nahass R, Ghalib R, Gitlin N, Herring R, Lalezari J, Younes ZH, Pockros PJ, Di Bisceglie AM, Arora $S$, Subramanian GM, Zhu Y, Dvory-Sobol H, Yang JC, Pang PS, Symonds WT, McHutchison JG, Muir AJ, Sulkowski M, Kwo P; ION-2 Investigators. Ledipasvir and sofosbuvir for previously treated HCV genotype 1 infection. N Engl J Med. 2014;370:1483-93.

83. Buti M, Gordon SC, Zuckerman E, Lawitz E, Calleja JL, Hofer H, Gilbert C, Palcza J, Howe AY, DiNubile MJ, Robertson MN, Wahl J, Barr E, Forns X. Grazoprevir, elbasvir, and ribavirin for chronic hepatitis $C$ virus genotype 1 infection after failure of pegylated interferon and ribavirin with an earlier- generation protease inhibitor: Final 24-eeek results from C-SALVAGE. Clin Infect Dis. 2016;62:32-6.

84. Chopra S, Graham CS. Treatment regimens for chronic hepatitis C virus genotype 2 and 3 infection in adults. Di Biscegile AM (ed). Last accessed date: 11.09.2017. Available from: www.uptodate.com

85. Gane EJ, Shiffman ML, Etzkorn K, Morelli G, Stedman CAM, Davis MN, Hinestrosa $F$, Dvory-Sobol $H$, Huang KC, Osinusi A, McNally J, Brainard DM, McHutchison JG, Thompson AJ, Sulkowski MS; GS-US-342-1553 Investigators. Sofosbuvir-velpatasvir with ribavirin for 24 weeks in hepatitis $\mathrm{C}$ virus patients previously treated with a direct-acting antiviral regimen. Hepatology. 2017;66:1083-9.

86. Zeuzem S, Dusheiko GM, Salupere R, Salupere R, Mangia A, Flisiak R, Hyland RH, Illeperuma A, Svarovskaia E, Brainard DM, Symonds WT, Subramanian GM, McHutchison JG, Weiland O, Reesink HW, Ferenci P, Hézode C, Esteban $\mathrm{R}$; VALENCE Investigators. Sofosbuvir and ribavirin in HCV genotypes 2 and 3. N Engl J Med. 2014;370:1993-2001.

87. Kowdley K, Bacon B, Dieterich D. Efficacy evaluation of 24 week SOF + $\mathrm{RBV}$ in a heterogeneous, real-world population of genotype $3 \mathrm{HCV}$ patients: Data from the TRIO network. Presented at the 50th Annual Meeting of the European Association for the Study of the Liver (EASL), Vienna Austria, 2015;62(Supplement 2):665-6.

88. Feld JJ, Ramji A, Shafran SD, Willems B, Marotta $P$, Huchet E, Vachon ML, Svarovskaia ES, Huang KC, Hyland RH, Yun C, Massetto B, Brainard DM, McHutchison JG, Tam E, Bailey R, Cooper C, Yoshida EM, Greenbloom S, Elkhashab M, Borgia S, Swain MG. Ledipasvir-sofosbuvir plus ribavirin in treatment-naive patients with hepatitis $C$ virus genotype 3 infection: An open-label study. Clin Infect Dis. 2017;65:13-9. 